\title{
Diversity, flexibility, and the resilience effect: lessons from a social- ecological case study of diversified farming in the northern Great Plains, USA
}

\author{
Liz Carlisle $^{1}$
}

ABSTRACT. Social-ecological systems are considered resilient when they are capable of recovering from externally forced shocks. Thus, whether a given system is identified as resilient depends on a number of contested definitions: what constitutes a shock, what constitutes a discrete system, and what constitutes acceptable performance. Here, I present a case study in which outcomes apparent to both the researcher and the study subjects demonstrated resilience in effect: a group of farmers in the northern Great Plains in the north-central United States realized economically sufficient production during a low rainfall year when many others in the region did not. However, the researcher's attempt to model this case as a resilient system was continually challenged by qualitative findings, suggesting that these farmers did not experience the officially decreed "drought" year as a shock. Moreover, the social and ecological processes that produced a "resilience effect" functioned as open systems, and were not readily bounded, even in analytical terms. This is not to suggest that resilience is not an operationalizable concept. Rather, the series of processes which produce a resilience effect may be best understood within a broad framework attentive to diversity, flexibility, and relationships at multiple scales-instead of quantitative models focused on discrete moments of disturbance and adaptation.

Key Words: diversified farming system; diversity; drought; resilience; northern Great Plains, USA; scale; slow variables; social-ecological systems; sustainable agriculture; values-based supply chain

\section{INTRODUCTION: AN INDUCTIVE APPROACH TO SOCIAL-ECOLOGICAL RESILIENCE}

The lexicon of "social-ecological resilience" has proven popular with scholars, policymakers, and land managers alike (Adger 2000; Berkes et al. 2003; Olsson et al. 2004; Folke 2006; Maguire and Cartwright 2008; White 2008a, 2008b; World Resources Institute 2008; Barthel et al. 2010; Davidson 2010; Folke et al. 2010; Derissen et al. 2011). Given the recent global increase in extreme weather events, and heightened concerns about future drought and flooding, "resilience" increasingly appears in place of the more general term "sustainability", the latter of which has been thoroughly critiqued as too broad (Lélé 1991, Adams 1995, McManus 1996, McGregor 2004, Morse and Fraser 2005, Francis et al. 2007). Social-ecological resilience would seem to answer the call for a framework that responds more directly to global social and environmental challenges, while explicitly acknowledging the "coupling" of human and natural systems. And yet, resilience has proven a vexing term in its own right, as scholars debate how best to connect its theory with its empirics (Carpenter et al. 2001, Cumming et al. 2005, Fischer et al. 2009, Thrush et al. 2009). Despite the enthusiastic development and amendment of resilience models, even the most elegant diagrams remain difficult to operationalize. Critics note with frustration that very few studies actually measure resilience (Brand and Jax 2007); and, while some scholars and practitioners are more interested in quantitative specificity than others, ${ }^{1}$ they share a palpable concern to "get the model right".

Another possible response to this impasse, however, is to conceptualize resilience in the reverse direction. Instead of trying to develop a more universally applicable model, how might we build our understanding of resilience inductively, based in particular cases? As Sayre (2004) convincingly argues for the case of ranch management, inductive studies have at least three advantages over quantitative, deductive ones: they can uncover unanticipated factors that have eluded previous research, they are better suited for understanding producers' mental models, and they offer greater temporal depth. Thus, inductive research can serve as an elucidating complement to deductive studies of the same phenomena (Schrader-Frechette and McCoy 1993, Berkes et al. 2003, Foster 2006, Fortmann et al. 2008). In the following article, I take this inductive approach, arriving at a working understanding of social-ecological resilience through ethnographic research of an agricultural values-based supply chain on the northern Great Plains, an ecological region spanning parts of Montana, the Dakotas, Nebraska, Wyoming, and southern Alberta and Saskatchewan, known for its low and volatile moisture and what appears to be the early onset of climate change. Having persisted through several severe droughts, this network of dryland farmers has made significant strides toward achieving the ends that motivate resilience scholarship and policy: healthy livelihoods and landscapes amidst challenging social and ecological conditions.

\section{CASE STUDY: A VALUES-BASED AGRICULTURAL SUPPLY CHAIN ON THE NORTHERN GREAT PLAINS}

The 2012 growing season was a historically dry year for American grain farmers. Eighty percent of U.S. agricultural land experienced drought in 2012, which made that year's dry spell more extensive than any since the 1950s (Economic Research Service 2012). I was thus surprised to hear that a group of farmers on the northern Great Plains in the north-central United States had been satisfied with their 2012 harvest and did not consider it a bad season. I had spoken extensively with these producers about the most recent serious drought year in the region - 1988 - which several had characterized as their "toughest time". So why, in 2012, 
were they flourishing? One easy explanation was that the 2012 drought was most severe east of here, in the midwestern corn and soybean belt. However, as local agricultural news media reported every day, it was still a hot, dry summer on the northern Great Plains. Six of the eight counties in which this group of producers farmed were granted federal drought designations during the 2012 growing season. If these growers had averted disaster, it was not because they had been spared the bad weather.

This study is based on extensive field research with this group of farmers, who have initiated a movement to grow and market ecologically appropriate rotation crops. Crop rotation is an ancient strategy for managing agricultural fields to maintain fertility. Throughout history, farmers worldwide have typically planted a sequence of crops that provide complementary nutrients and break up pest and disease cycles. However, the industrial model of agriculture, increasingly prevalent since World War II, has instead encouraged repeated plantings of the same crop, which depend on chemical fertilizers and pesticides.

Convinced that chemically supported monocultures were socially and ecologically unsustainable, four farmers in north central Montana founded a small processing and marketing business in 1986 to create an alternative to the commodity market that would allow them to recover the wisdom of rotation. Because the agricultural economy on the northern Great Plains is based on cereal grains, which deplete soil nitrogen, this processor/marketer focused on legumes (plants that can convert atmospheric nitrogen into a soil-available form and exude it through their roots).

The processor/marketer now contracts with a loose network of 15 to 20 producers, whose farms range in size from a few hectares to nearly 4000 , but typically include about 400 to 800 ha of cropland-which is a modest area by the standards of contemporary grain agriculture. By design, no producer grows exclusively for this single processor/marketer. Rather, growers market high-value rotation crops through this "values-based supply chain" (VBSC) ${ }^{2}$ in order to support diverse operations that include other enterprises, such as animal agriculture and direct market produce. On a small but meaningful scale, members of the VBSC have replaced industrial grain monoculture with lowinput, biologically diverse farming systems. (See Appendix 1 for a map and rotation plan from one member farm.)

At the close of the 2012 growing season, the CEO of the VBSC estimated the overall moisture for his growing region to be $40 \%$ of the previous year's level (D. Oien, personal communication). Yet, he reported that his suppliers' farms achieved about $80 \%$ of the previous year's production-and that his post-harvest inventory of marketable product was at normal levels. In this article, I draw on qualitative research with members of this VBSC and their broader networks to explain this "resilience effect".

\section{METHODS: INVESTIGATING AN AGRICULTURAL SUPPLY CHAIN AND ITS ECOSYSTEM}

To find out how the VBSC achieved this resilience effect, I undertook research typical of a supply chain study: I conducted interviews, surveys, and field visits with each producer, as well as with the full staff at the processing plant and several downstream buyers. I supplemented these methods with a more "ecological" approach, aiming to understand the VBSC as the product of its connections and relationships, including those not formalized by market transactions or contractual ties. By design, this research did not begin with an a priori model of the VBSC as a tightly bound "closed system". Rather the VBSC presented an observable "resilience effect" that could be analyzed as a case, with attention to its broader connections and context. Hence, I used "snowball sampling" to identify the diverse network of nongovernmental organizations, university-based researchers, socially responsible investors, current and former agency personnel, and nonaffiliated producers who are key to the success of the VBSC. In all, I completed in-depth interviews with 25 growers, 15 other members of the supply chain, and 12 technical assistance personnel (Appendix 2). ${ }^{3}$ To verify farmers' selfreported soil quality, soil moisture, and management practices, I made field visits to 19 farms. I also accompanied organic inspectors and the owner of the VBSC on similar field visits, and attended farm tours, workshops, and work parties as a participant-observer, which helped me "read between the lines" of interviews and ecological data to see how key social and ecological processes functioned in practice. Finally, I consulted oral histories and archives maintained by the Montana Historical Society, the Alternative Energy Resources Organization, and the VBSC to understand "slow variables"-ranging from soil moisture conservation to the development of cooperative economic practices and civil society groups - at larger temporal scales. I conducted most of this research during the 2011 and 2012 growing seasons, but follow-up has continued through 2013. And, I have been in contact with members of the VBSC since 2008, when I was employed as an agriculture and natural resource policy staffer for a United States Senator. Further description of my methods and data can be found in the appendices to this article.

\section{RESULTS: "SLOW VARIABLE" DIVERSITY AND FLEXIBILITY AT MULTIPLE RELATIONAL SCALES}

The "resilience effect" I observed within this VBSC - healthy landscapes and economically sufficient production during low rainfall years - hinged on both diversity and flexibility. Flexible diversification characterized not just the VBSC's member farms, but also the "slow variables" (Carpenter et al. 2001) that determined these farms' underlying capacity to provide ecosystem services, and connected farmers to the larger social-ecological system of which they were a part. Slow variable processes of flexible diversification - such as the development of waterconserving crop rotations, the creation of values-based supply chains, and shifts to a mental model of agriculture rooted in soil health-were interwoven across relational scales, based on degrees of social and ecological proximity rather than strict geographic nearness. Beginning at the smallest of these scales, I identify the processes most clearly related to resilient outcomes and map the links through which such processes demonstrate a tendency or potential to scale up.

\section{Individual scale: paradigm shift}

While VBSC producers were far from being fully self-sufficient, slow variable processes at the individual scale were nonetheless key to their resilience. What producers characterized as a "paradigm shift", or simply "transition", marked a key internal transformation, a process related to, but distinct from changes in the ecological management of their farms. This internal shift was expressed as a transition from focusing on annual yield to focusing on the long-term health of the whole farm system-usually 
described as fundamentally based in soil, but also including plants and animals, and often farmers and their communities (Appendix $3)$.

Contrary to classical resilience thinking (Walker and Cooper 2011), this paradigm shift did not require a catalyzing crisis, nor was crisis sufficient to produce it (neighbors of VBSC members could face and recognize the same problems of drought and debt without changing their paradigm). Rather, this individual-scale process was described as a long-simmering development of what social movement theorists call consciousness (Freire 1970, Gramsci 1996), informed by an individual's entire life experience. To experience a paradigm shift, producers needed a theory, not just a problem. Farmers re-oriented their focus from maximizing the exchange value of resources leaving the system to sustaining and renewing the use value of resources remaining in the system (Appendix 3). Somewhat paradoxically, this more intensive form of management required increased engagement with processes at broad spatial and temporal scales.

\section{Farm scale: low-input management of diverse acgroecosystems} Individual-scale paradigm shifts supported and encouraged resilience at the farm scale, which was characterized by low-input management of diverse agroecosystems (Appendix 1). For this context-dryland farming on the northern Great Plains-a particularly important farm-scale process was conservation of soil water. Producers planted a variety of drought-tolerant crops and maintained soil cover throughout the year in order to retain soil moisture (Appendix 4). These water-conserving measures also served to return key nutrients and organic matter to the soil, and formed part of a larger whole-farm management strategy.

VBSC producers grew an average (mean) of 9.4 crops, including 5.07 grains, two pulses, and assorted edible oilseeds, legumes, biofuels, and hay. Average rotation length was 6.08 years. In addition, just over half of the producers grew diverse vegetable gardens for personal use or direct marketing. Seventy-three percent also raised animals on their farm, and $93 \%$ had substantial acreage of uncultivated land in native pasture, seeded pasture (sometimes restored from former cropland), borders, hedgerows, conservation plantings, or cover crops. Cover crops were used by all but one VBSC member, and these were diverse too: farmers raised an average of 5.31 different types, either in mixtures or in rotation. This level of on-farm diversity contrasted sharply with the adjacent landscape of grain monoculture. In the eight counties where this VBSC's producers are located, over $81 \%$ of harvested cropland is devoted to either wheat or barley (USDA 2007). Typical rotations in the region alternate among wheat, barley, and summer fallow, without a nutrient-building or cover crop in between, although interest in pulse and cover crops is growing $(\mathrm{N}$. Matheson, G. Jackson, and D. Wichman, personal communications).

\section{Enterprise scale: diversification of markets}

On-farm resilience was interdependent with resilience at a related, but distinct scale: the farm enterprise. Exceeding the geographical boundaries of the farm itself, the enterprise was the scale at which rural families confronted the interface between their land and the markets that determined whether this land's produce was sufficiently "valuable" to support a household. Because diversified farms were often economically insufficient in the context of the commodity market, individual paradigm shifts and ecological farm management went hand in hand with enterprise transition: reducing input costs and selling into a diversity of VBSCs and direct markets. VBSC producers reported a median of nine different markets, excluding direct market consumers. Eighty percent contracted with multiple VBSCs. A slightly different $80 \%$ sold at least one product directly and/or through local retailers, although this was not a substantial market for most. Fifty-three percent sold both crops and livestock/animal products, and approximately half hosted bees in exchange for honey or cash payment. This level of diversification contrasted sharply with typical farm enterprises in the region, which generally sold wheat to a single multinational corporation, perhaps sold malting barley to another multinational corporation, and might have direct local markets for hay and/or feed barley (N. Matheson and D. Wichman, personal communications).

For the diversified farmers of the VBSC in this case study, rotation planning linked on-farm ecological resilience and beyond-farm enterprise resilience, and in a market context they were each necessary for supporting one another (Appendix 5). Emergent benefits of this diversity were manifold, because farmers gained more flexibility to work within ecological constraints. Producers whose enterprises included livestock had the option to graze down the stubble of an economic crop or cover crop, while growers who had markets for legumes or buckwheat could use these crops as nutrient-building green manures if weather or poor prices made it economically unfeasible to harvest them. Importantly, the connection between on-farm resilience and enterprise resilience was more complex and bidirectional than a simple market signal - the relationships developed between farms and enterprises encouraged diversity on both ends.

For most producers, however, successful enterprise resilience required diversification outside the parameters of their "paradigm shift" and ecological management approach. To construct economically secure enterprises, $73 \%$ of the farmers sold to non-values-based supply chains (typically large corporations), and $47 \%$ sold into conventional commodity markets. The link between farm scale and enterprise scale, then, was one juncture at which resilience could break down-if enterprise options were not sufficient to support optimal farmscale diversity.

\section{Multifarm scale: cooperative economy}

At one scale higher, resilience among VBSC farmers also relied on cooperative activity with one another. All but two interviewees reported some multifarm cooperation, and, overall, respondents characterized other farmers as the second-highest source of support for their agroecological operations, behind "personal values". Such multifarm cooperation was critical to resilience at the single farm scale, because while diversified operations are knowledge- and labor-intensive, these costs can often be shared, thus reducing the burden on any one household. For example, utilizing diverse rotations often means having different equipment for smaller seeded crops and larger seeded ones, but because each machine is in use for only a small portion of the rotation, equipment can be circulated among several area farms. Similarly, troubleshooting complex rotations requires several seasons of observation, but comparing notes with similar operations nearby shortens the learning curve, which can mean the difference 
between a successful harvest and bankruptcy. The institutionalization of informal farmer cooperation, often neglected in descriptions of agroecological resilience, proved key for this case. The leap from informal mutual aid among individual farmers to cooperatively building new institutions (e.g., a processing facility for alternative crops, a farmer science network for trialing agroecological crops and practices) was critical to linking on-farm and enterprise diversity and was anything but automatic. Rather, multifarm institution building hinged on longterm processes deeply embedded in the agrarian history of the region: the development of organizational skills, political will, and familiarity with institutions and their pitfalls.

\section{Network scale: civil society groups focused on advocacy and technical support}

Multifarm resilience, in turn, relied on an even larger scale process: the formation of civil society groups focused on advocacy and technical support for sustainable agriculture (Appendix 6). In particular, a Farm Improvement Club program supported by small grants from the nonprofit Alternative Energy Resources Organization (AERO) helped farmers organize collective work and access resources. This program sponsored farm-scale participatory research, field days, and annual conferences. When farmer clubs encountered regulatory or policy hurdles, the sponsoring nonprofit also provided a vehicle for mobilizing political action in partnership with farmers in other communities. Such "networked" resilience was both critical to processes at other scales and entirely dependent upon them. Broad-based civil society groups like AERO, the Farmer's Union, and the Montana Organic Association were key to the production and reproduction of the theory that undergirded paradigm shifts, technical assistance that enhanced farm-scale resilience, and social learning forged connections among farmer-cooperators. These groups responded to several needs at smaller scales: individuals needed a means of organizing and meeting others who had experienced similar "paradigm shifts", farms transitioning to diversified production needed resources and advocates, and enterprises required financial, and often political, backing. However, facilitative organizations also relied on the smaller scale processes they supported. When ties to the "grassroots" broke down, organizations either folded or changed in focus (Appendix 6, Humphries et al. 2008).

\section{Public scale: safety nets and supportive policy}

The previous five scales are perhaps the limit of what might typically be understood as a social-ecological system within the classical resilience framework. Yet, as several scholars have pointed out (Taylor 2005, Turner 2010, Watts 2013), the preceding discussion does not exhaust the cross-scale linkages integral to achieving resilient outcomes. At the broadest scale, resilience among case study farmers relied on public policy and public safety nets, such as crop insurance, health insurance, and conservation programs. Intertwined with processes at the other five scales, processes at this public scale were of key importance, because this was the scale at which the benefits of resilience met the investments necessary to resilience - the final accounting place at which crossscale debts at lower levels could be settled. Without the security of this broad-scale settling up, resilience required rather dramatic subsidization (of community water quality by a handful of farm households, for example) that relied on extraordinary individual commitments of time, energy, and risk. Stronger safety nets allowed farmers to contribute time, energy, and resources to the long-term health of social-ecological communities - investments which were prudently conservative at larger temporal scales, but risky on an interannual basis, because they reduced liquid capital and labor time that would otherwise be available to respond to unexpected financial and climatic shocks.

This case study demonstrated that some public safety nets and public programs were effectively supporting multiscalar resilience. Cost-share for conservation measures through Natural Resource Conservation Service programs such as EQIP (Environmental Quality Incentives Program) had helped $73 \%$ of the VBSC farmers invest in long-term farm system improvements, such as tree plantings and perennial border strips. Other programs were helpful but incomplete. Federal crop insurance, previously available only for wheat and barley in this region, had been extended to cover legumes, but still left out many key rotation crops (such as sainfoin and buckwheat), and did not provide as much assistance for diverse crops as for conventional monocultures. Some safety nets were well resourced, but insufficiently linked to processes of resilience at other scales. The Natural Resource Conservation Service's Conservation Reserve Program, intended to prevent soil erosion, provided competitive income that had encouraged many producers in the region to cease cultivating some or all of their land. However, many case study producers claimed that this program was actually a detriment to responsible land stewardship, since the regulations had originally been written to encourage nondiverse conservation plantings and chemical treatments, and lucrative Conservation Reserve Program leases pushed rents beyond what dryland organic producers could afford (Appendix 7). Thus, the Conservation Reserve Program appeared to be a case of a well-intentioned public program that had drifted from its intended aims, for lack of a strong connection to grassroots actors at the farm, multifarm, and network scales.

In many cases, however, needed safety nets were simply absent. In particular, lack of access to affordable health care impeded processes of resilience at the farm and enterprise scales, by reducing the ability and willingness of farmers to take risks and reducing the availability of labor for time-intensive agroecological management. Six of the fifteen currently active producers who responded to questions about household finances were uninsured or underinsured, eight cited health care as a significant financial hardship, and seven of the nine households that reported off-farm employment cited health coverage as the main reason for seeking nonfarm work (Appendix 8). Whether they went without coverage or dedicated a large share of their income to minimal protection from catastrophic policies, health care was characterized by several farmers as the greatest source of economic vulnerability for their household. While growers could mitigate other sources of vulnerability-by reducing their use of off-farm inputs and selling into a diverse combination of VBSCs - they could not control whether they got sick (although many said eating their own organic produce and pursuing an active lifestyle was, in part, a strategy for staying out of the hospital).

Where safety nets and supportive public policies were absent, farmers worked to self-organize and find do-it-yourself solutions, as they did at other scales. Several interviewees commented wryly that older farmers had essentially fashioned a de facto retirement 
system out of the Conservation Reserve Program, although they questioned the ecological wisdom of paying producers to "take out the whole farm and move to Arizona". Similarly, neighborhood fundraisers to cover expensive health care procedures were common in this region. Much like any homespun, patchwork creation, these self-fashioned safety nets were charming, but prone to holes, and such gaps affected some producers more than others. The ability and desire to invent one's own safety net was key to being able to afford the risk of ecological diversification away from the prevailing commodity system. Yet, this ability and desire was contingent on a number of factorshealth and family status, whether one partner worked, access to military retirement or a pension from a previous career. Thus, this safety net scale was the one at which opportunities for diverse, flexible approaches to agriculture were the most stratified.

\section{DISCUSSION AND CONCLUSIONS}

Admittedly, this article does not engage in a genealogy of socialecological resilience thinking (for an excellent one, see Walker and Cooper 2011), and it could be argued that I am disregarding the complex history of this term and its development. However, my contention is that, while such genealogies deserve careful attention, meaning is also constructed by actors who fall outside such analyses. Wherever groups of people develop and share "working knowledge", it is well worth investigating empirically (Kloppenburg et al. 2000). As Taylor (2005) notes, the term "system" (and, by association, classical definitions of resilience) formally refers to coherent dynamics that are internal to a boundary, but in common usage the term may simply connote a set of interacting elements. Despite the term's mathematical history, he suggests, we might take seriously this drift in its applied meaning. What if, Taylor proposes, we understood complexity in terms of intersecting processes, including history and contingent dynamics, rather than as a property of well-bounded systems?

Following this empirical approach, I arrived at a modified, but workable understanding of resilience through this case study. Based on the findings above, this VBSC on the northern Great Plains does not appear to be a closed-loop, resilient system. What this research uncovered, rather, was the multiscalar "underground" needed to support a "triple bottom line" 4 supply chain if it is to deliver on its promise of social-ecological resilience. In addition to illustrating the importance of multiple geographical and social scales - up to the level of public safety nets - this case study also highlights the temporal dimension of multiscalar social-ecological resilience. At each of the scales discussed above, history mattered, and not all the slow variable components of social-ecological resilience could have been established within the short time frame typically associated with the launch of an enterprise. For example, individual paradigm shifts relied on multigenerational processes of social learning, dating back to experiences with early twentieth century grain monopolies and the cooperative wheat pools formed in response. A sophisticated understanding of local ecology and the political economy of grain agriculture had been passed down through families and organizations like the Farmer's Union, along with models for cooperative marketing, on-farm research, and advocacy (Appendix 6). This temporal dimension of resilience squares with Berkes et al.'s (2003) findings on system "memory" and with Carpenter et al.'s (2001) emphasis on social and ecological slow variables. Yet these authors focus their attention at the institutional scale, as the site of learning and discovery that promotes system reorganization. While I found institutions and organizations important, I found their capacity to support resilience to be interdependent with processes at yet larger scales, i.e., processes not readily contained within analytically bounded systems.

If this case study suggests that processes at the very largest of scales - spatial and temporal, ecological and social-are critical to resilience at even the smallest of scales, where does that leave our understanding of resilience? If we cannot analytically bound a system, how can we distinguish resilience from nonresilience?

In some respects, this study's findings support recent critiques of the resilience framework. As several scholars have pointed out, resilience involves both social and ecological processes at multiple scales (Carpenter et al. 2001, Olsson et al. 2004, Folke 2006). Moreover, these processes are densely interconnected, which complicates any attempt to isolate one or two factors as being most important in explaining outcomes (Taylor 2005). Defining resilience and its key indicators such that the concept can be applied by modelers to collect and quantify data is indeed frustrating. From a modeler's vantage point, one might conclude that the term social-ecological resilience does not yet have precise, operationalizable meaning (Brand and Jax 2007), or is more properly understood as a discourse or heuristic (Watts 2013).

And yet, I also found that social-ecological resilience is understood as a coherent and meaningful concept in practice. Producers used the term resilience themselves, both in interviews and in conversations with one another. They identified the multiscalar complexities characterized by academics as problems with the social-ecological resilience framework, and were well aware that their condition was one of profound interdependence, which could never be fully captured by discrete "indicators". Yet, because these producers were not tasked with measuring resilience, but rather with achieving it, the resilience framework's inherent holism and irreducibility to isolable variables was not an insurmountable difficulty for them. ${ }^{5}$ Rather, their working knowledge of resilience embraced the gestalt-like nature of the concept, taking shape as a practical question that guided their approach to flexible diversification: what needs to be shared with whom, and at what scale, in order to flourish?

\section{What needs to be shared with whom, and at what scale, in order to flourish?}

This guiding point of inquiry, which appeared to be at the heart of the VBSC's success story-allowed farmers to approach ecology, farm management, and political questions in an integrated fashion. Such working knowledge of resilience did not require producers to bound their communities. Farmers did not need to measure, specify, and identify a disturbance to know when or how to adapt. Rather, effective resilience hinged on continual, everyday processes of learning, adjustment, cooperation, and long-term planning. As farmers shared ecologies, knowledge, labor, and resources at various scales, they developed "transformatively adaptive" agricultural and social systems that addressed underlying biophysical and political economic vulnerabilities (Bassett and Fogelman 2013). Rather than managing bounded, closed-loop systems, farmers had to choose appropriate scales of action for each process, linking across scales through the intertwining of these processes. The major difference 
between these farmers and their neighbors was that their observational scale was often quite broad.

Commodity farmers in the region, it could be argued, were also pursuing a form of resilience, but typically at a smaller timescale: that of a single generation. Although the form of farm management required by their marketing strategy left these commodity farmers vulnerable to climatic and market fluctuations, the system of federal commodity subsidies and crop insurance that had been in place throughout this generation could mitigate such impacts, thus providing immediate economic security not available to the farmers who pursued alternative crops and markets. However, over the course of two to three generations, the combined economic and ecological vulnerabilities inherent to commodity grain production led to the failure of most family farms in America's interior (Harl 1990, Davidson 1996).

The farmers in this case study, observing their farm communities at multigenerational timescales, concluded that commodity agriculture was too risky - and that the constraints of their land were ultimately more fundamental than those imposed by contemporary commodity markets. After all, the main reason the 2012 drought was characterized as less severe in this region, when compared with harder hit portions of the midwest, was not that the northern Great Plains was not dry. Rather, it was always dry. The larger the observational timescale, the more certain this reality of low moisture. Thus, rather than attempting to manipulate their farm's ecology to align with agribusiness (as most of their neighbors had), these farmers instead manipulated their farm's economy to align with the region's ecological constrains, such that the variability of moisture had a dampened effect on farm viability.

Instead of basing their resilience in the existing structure of federal subsidies and commodity markets, these farmers made a "paradigm shift" to focusing on the fundamental slow variable safety net of conserved soil moisture and organic matter, then scaled up their approach to resilience from there. At the farm scale, they made regular, consistent ecological investments, even in years when the rain was plentiful and markets were high. They learned to ask less of their soils, so that dry seasons were not a disastrous anomaly, but part of expected variation. To make their ecologically appropriate cropping systems generate a reliable livelihood, they needed to cooperate at the multifarm scale. They not only developed VBSCs, but also organized at yet larger scales to form civil society groups. These groups provided technical support and advocated for state and federal policy change.

Over multigenerational timescales, farmers thus arrived at an understanding of periodic "farm crises" quite distinct from typical characterizations of drought. The cause of farm-scale crisis, as they experienced it, was not climatic variability, but the incommensurability of that climatic variation and the inflexible demands of the commodity system. In sum, these farmers experienced "drought" as a manageable phenomenon, because it resulted not from (inevitable) climatic variability but from (contingent) processes of economic and biological overconcentration. They could mitigate these contingent processes, not through adaptation to shock, but through flexible, everyday diversification that allowed them to avoid shocks in the first place. By cultivating broad-based social and ecological complementarities, farmers shared the wealth - and the risk - at multiple scales.
While the findings of this case study are necessarily limited, I suspect the "guiding question" I saw at work among this group of farmers bears a family resemblance to the land ethic described by Knapp and Fernandez-Gimenez $(2008,2009)$ as a central analytic for Rocky Mountain ranchers, or for that matter, the "rationality of resilience" that Hannah Wittman (2010) finds in use among members of Brazilian peasant movements, who emphasize " agrarian citizenship" and "systems of mutual obligation". Such empirical, qualitative research in particular places can greatly improve our understanding of the set of intersecting processes that produce a "resilience effect"-and farmers' working knowledge is a good place to begin.

Responses to this article can be read online at: http://www.ecologyandsociety.org/issues/responses. $\mathrm{php} / 6736$

\section{Acknowledgments:}

The ideas expressed in this paper emerged during conversations with farmers, ranchers, and technical assistance providers, to whom I owe no small intellectual debt. I am especially grateful to Vilicus Farms for contributing their farm map and rotation plan as an appendix to this article. Colleagues at UC Berkeley, particularly members of the Diversified Farming Systems working group and the Berkeley Food Institute, were invaluable interlocutors. Nathan Sayre, Annie Shattuck, Claire Kremen, Margot Higgins, Jeff Martin, Shannon Cram, Adam Romero, Paul Roge, Gustavo Oliveira, Jennifer Baca, and Andrew Friedman read earlier drafts of this paper and provided incisive feedback. This article benefited, as well, from helpful comments and suggestions made by the editors at Ecology and Society and by two anonymous reviewers. Fieldwork was funded by a Graduate Research Fellowship from the National Science Foundation and a grant from the Charles Redd Center; writing was completed with the support of Soroptimist International's Founder Region Dissertation Fellowship, the P.E.O. Scholar Award, and the University of California-Berkeley's Graduate Division; and publication fees were supported by the Associated Students of the University of California's Student Opportunity Funds.

\section{LITERATURE CITED}

Adams, W. M. 1995. Green development theory? Environmentalism and sustainable development. Pages 87-99 in J. Crush, editor. Power of development. Routledge, New York, USA and London, UK.

Adger, W. N. 2000. Social and ecological resilience: are they related? Progress in Human Geography 24(3):347-364.

Barthel, S., C. Folke, and J. Colding. 2010. Social-ecological memory in urban gardens-retaining the capacity for management of ecosystem services. Global Environmental Change 20:255-265. http://dx.doi.org/10.1016/j.gloenvcha.2010.01.001

Bassett, T. J., and C. Fogelman. 2013. Déjà vu or something new? The adaptation concept in the climate change literature. Geoforum 48:42-53. http://dx.doi.org/10.1016/j.geoforum.2013.04.010 
Berkes, F., J. Colding, and C. Folke, editors. 2003. Navigating social-ecological systems: building resilience for complexity and change. Cambridge University Press, Cambridge, Massachusetts, USA. http://dx.doi.org/10.1017/CBO9780511541957

Brand, F. S., and K. Jax. 2007. Focusing the meaning (s) of resilience: resilience as a descriptive concept and a boundary object. Ecology and Society 12(1):23. [online] URL: http://www. ecologyandsociety.org/vol12/iss1/art23/

Carpenter, S., B. Walker, J. M. Anderies, and N. Abel. 2001. From metaphor to measurement: resilience of what to what? Ecosystems 4(8):765-781.

Cumming, G. S., G. Barnes, S. Perz, M. Schmink, K. E. Sieving, J. Southworth, M. Binford, R. D. Holt, C. Stickler, and T. Van Holt. 2005. An exploratory framework for the empirical measurement of resilience. Ecosystems 8:975-987. http://dx.doi. org/10.1007/s10021-005-0129-Z

Davidson, D. J. 2010. The applicability of the concept of resilience to social systems: some sources of optimism and nagging doubts. Society and Natural Resources 23(12):1135-1149. http://dx.doi. org/10.1080/08941921003652940

Davidson, O. G. 1996. Broken heartland: the rise of America's rural ghetto. University of Iowa Press, Iowa City, Iowa, USA.

Derissen, S., M. F. Quaas, and S. Baumgartner. 2011. The relationship between resilience and sustainability of ecologicaleconomic systems. Ecological Economics 70(6):1121-1128. http:// dx.doi.org/10.1016/j.ecolecon.2011.01.003

Economic Research Service. 2012. U.S. drought 2012: farm and food impacts. United States Department of Agriculture, Washington, D.C., USA.

Fischer, J., G. D. Peterson, T. A. Gardner, L. J. Gordon, I. Fazey, T. Elmqvist, A. Felton, C. Folke, and S. Dovers. 2009. Integrating resilience thinking and optimisation for conservation. Trends in Ecology and Evolution 24(10):549-554. http://dx.doi.org/10.1016/ j.tree.2009.03.020

Folke, C. 2006. Resilience: the emergence of a perspective for social-ecological systems analyses. Global Environmental Change 16(3):253-267. http://dx.doi.org/10.1016/j.gloenvcha.2006.04.002

Folke, C., S. R. Carpenter, B. Walker, M. Scheffer, T. Chapin, and J. Rockström. 2010. Resilience thinking: integrating resilience, adaptability and transformability. Ecology and Society 15(4):20. [online] URL: http://www.ecologyandsociety.org/vol15/iss4/ $\underline{\operatorname{art} 20 /}$

Fortmann, L., editor. 2008. Doing participatory research in conservation and rural livelihoods: doing science together. WileyBlackwell, Chichester, West Sussex, UK.

Foster, K. A. 2006. A case study approach to understanding regional resilience. University of California Institute of Urban and Regional Development, Berkeley, California, USA.

Francis, C., R. Elmore, J. Ikerd, and M. Duffy. 2007. Greening of agriculture: is it all a greenwash of the globalized economy? Journal of Crop Improvement 19(1/2):193-220.

Freire, P. 1970. Pedagogy of the oppressed. Continuum, New York, New York, USA.
Gramsci, A. 1996. Antonio Gramsci, prison notebooks, volume 2. Joseph A. Buttigieg, editor and translator. Columbia University Press, New York, New York, USA and Chichester, West Sussex, UK.

Harl, N. E. 1990. The farm debt crisis of the 1980s. Iowa State University Press, Ames, Iowa, USA.

Humphries, S., J. Jimenez, F. Sierra, and O. Gallardo. 2008. Sharing in innovation. Pages 36-54 in L. Fortmann, editor. Participatory research in conservation and rural livelihoods: doing science together. Wiley-Blackwell, Chichester, West Sussex, UK.

Kloppenburg, J., S. Lezberg, K. DeMaster, G. W. Stevenson, and J. Hendrickson. 2000. Tasting food, tasting sustainability: defining the attributes of an alternative food system with competent, ordinary people. Human Organization 59(2):177-186.

Knapp, C. N., and M. E. Fernandez-Gimenez. 2008. Knowing the land: a review of local knowledge revealed in ranch memoirs. Rangeland Ecology \& Management 61(2):148-155. http://dx.doi. org/10.2111/07-088.1

Knapp, C. N., and M. E. Fernandez-Gimenez. 2009. Knowledge in practice: documenting rancher local knowledge in northwest Colorado. Rangeland Ecology \& Management 62(6):500-509. http://dx.doi.org/10.2111/08-175.1

Lélé, S. M. 1991. Sustainable development: a critical review. World Development 19(6):607-621.

Lerman, T. 2012. A review of scholarly literature on values-based supply chains. Sustainable Agriculture Research and Education Program, Agricultural Sustainability Institute, University of California, Davis, California, USA.

Maguire, B., and S. Cartwright. 2008. Assessing a community's capacity to manage change: a resilience approach to social assessment. Bureau of Rural Sciences, Australian Government, Canberra, Australia.

McGregor, A. 2004. Sustainable development and 'warm fuzzy feelings': discourse and nature within Australian environmental imaginaries. Geoforum 35(5):593-606.

McManus, P. 1996. Contested terrains: politics, stories and discourses of sustainability. Environmental Politics 5(1):48-73. http://dx.doi.org/10.1080/09644019608414247

Morse, S., and E. D. G. Fraser. 2005. Making "dirty" nations look clean: the nation state and the problem of selecting and weighing indices as tools for measuring progress towards sustainability. Geoforum 36(5):625-640.

Olsson, P., C. Folke, and F. Berkes. 2004. Adaptive comanagement for building resilience in social-ecological systems. Environmental Management 34(1):75-90. http://dx.doi.org/10.1007/s00267-003-0101-7

Olsson, P., C. Folke, and T. Hahn. 2004. Social-ecological transformation for ecosystem management: the development of adaptive co-management of a wetland landscape in southern Sweden. Ecology and Society 9(4):2. [online] URL: http://www. ecologyandsociety.org/vol9/iss4/art2/

Sayre, N. 2004. The need for qualitative research to understand ranch management. Journal of Range Management 57:668-674. http://dx.doi.org/10.2307/4004026 
Shrader-Frechette, K. S., and E. D. McCoy. 1993. Method in ecology: strategies for conservation. Cambridge University Press, Cambridge, UK. http://dx.doi.org/10.1017/CBO9780511623394

Taylor, P. 2005. Unruly complexity: ecology, interpretation, engagement. University of Chicago Press, Chicago, Illinois, USA. http://dx.doi.org/10.7208/chicago/9780226790398.001.0001

Thrush, S. F., J. E. Hewitt, P. K. Dayton, G. Coco, A. M. Lohrer, A. Norkko, J. Norkko, and M. Chiantore. 2009. Forecasting the limits of resilience: integrating empirical research with theory. Proceedings of the Royal Society B: Biological Sciences 276:3209-3217. http://dx.doi.org/10.1098/rspb.2009.0661

Turner, M. D. 2010. Climate change and social resilience: "adaptive" conflict in the Sahel. Paper prepared for the Berkeley Environmental Politics Workshop. Department of Environmental Science, Policy, and Management, College of Natural Sciences, University of California, Berkeley, California, USA.

United States Department of Agriculture. 2007. 2007 Census of agriculture, United States, summary and state data. Volume 1, Geographic Area Series, Part 51. AC-07-A-51. National Agricultural Statistics Service, Washington, D.C., USA. [online] URL: http://www.agcensus.usda.gov/Publications/2007/Full_Report/ Volume 1, Chapter 1 US/usv1.pdf

Walker, J., and M. Cooper. 2011. Genealogies of resilience from systems ecology to the political economy of crisis adaptation. Security Dialogue 42(2):143-160. http://dx.doi.org/10.1177/096$\underline{7010611399616}$

Watts, M. 2013. Silent violence. Second edition. University of Georgia Press, Athens, Georgia, USA.

White, C., editor. 2008a. Building resilience (Part 1). The Quivira Coalition Journal 32.

White, C., editor. 2008b. Building resilience (Part 2). The Quivira Coalition Journal 33.

Wittman, H. 2010. Reconnecting agriculture and the environment: food sovereignty and the agrarian basis of ecological citizenship. Pages 91-105 in H. Wittman, A. A. Desmarais, and N. Wiebe, editors. Food sovereignty: reconnecting food, nature and community. Fernwood Publishing, Halifax, Nova Scotia and Winnipeg, Manitoba, Canada.

World Resources Institute. 2008. Roots of resilience-growing the wealth of the poor. World Resources Report 2008. World Resources Institute, Washington, D.C, USA, in collaboration with United Nations Development Programme, United Nations Environment Programme, and World Bank.

${ }^{1}$ Witness the differences among Carpenter et al. 2001, Thrush et al. 2009, and Folke 2006.

${ }^{2}$ I follow Lerman's (2012) definition of values-based supply chains as "wholesale marketing channels or supply chains that preserve the identity of the farmers and ranchers who raised or grew the product being sold, as well as any environmental, social or community values incorporated into its production. These supply chains are characterized by trust, transparency and equitable relationship between all participants" and are intended to "ensure a fair price for farmers".
${ }^{3}$ Interview questions adapted, significantly, from Ryan Galt's interview schedule for qualitative research with Community Supported Agriculture farmers in California's Central Valley.

4 Committed to an expanded definition of economic value, focused on "people" and "planet", as well as "profit".

5 When producers were tasked with measuring standardized components of their diversified farming systems - typically by an organic certifier-they were quick to note that such datagathering exercises did a poor job of informing, evaluating, or describing the "resilience effect" on their farms. Their inspectors, most of whom were producers themselves, often agreed, as in the following exchange I recorded during an organic audit:

Inspector: The organic industry believes documentation is more important than how good the job gets done. A great example is the cleaning of the equipment. It's more important that (the farmer) writes it down than that he does it.

Farmer: The extra paperwork and extra hassle... Inspector: . . is worthless. 
Appendix 1: Farm Map and Rotation Plan, Courtesy of Vilicus Farms, Havre, MT (VBSC grower)

\section{Field Layout / 2012 Crop Plan}

Field I: 317.45 acres

FSA Farm / Tract Numbers: 5528 - 780

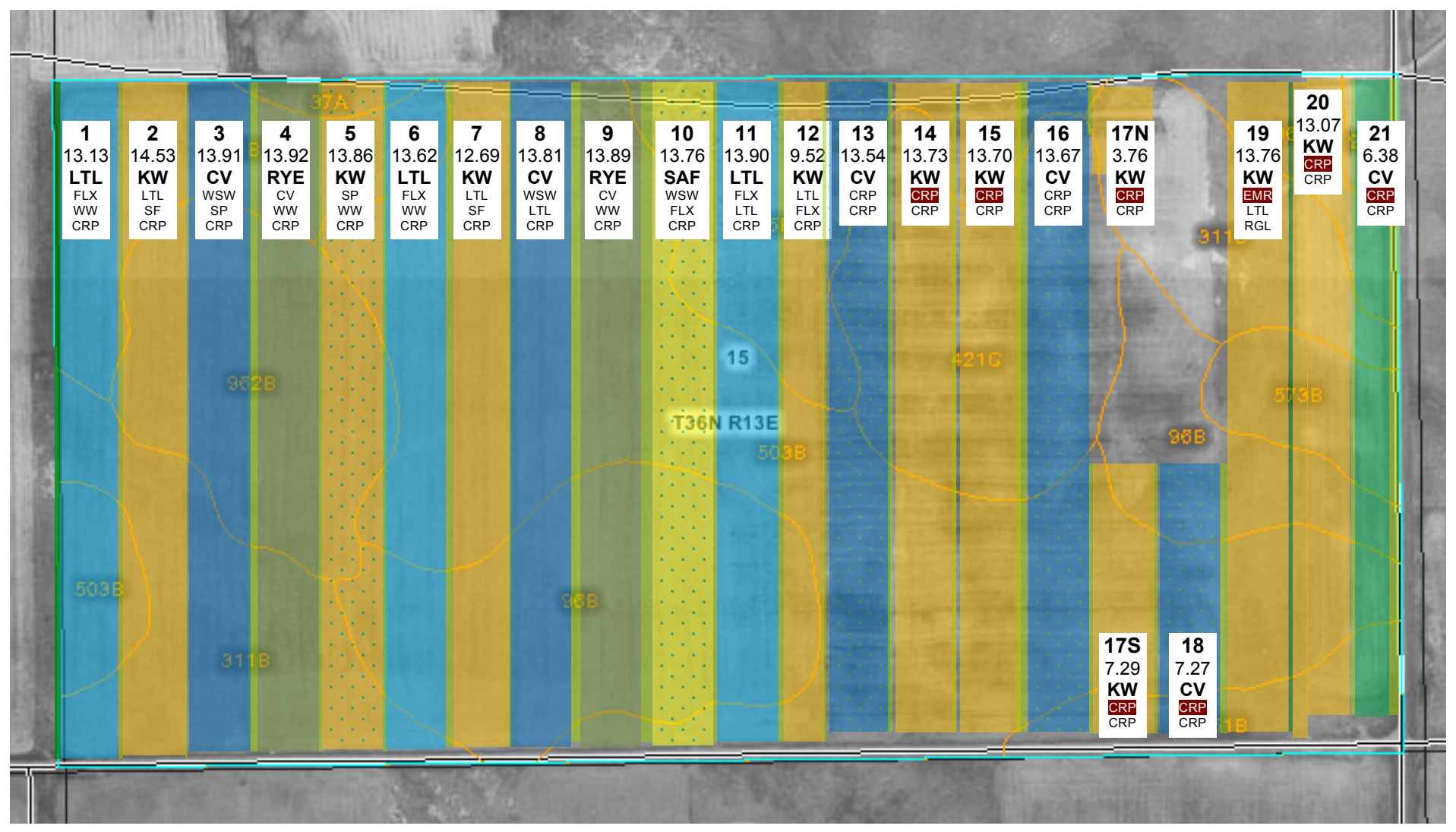

\begin{tabular}{|c|c|c|c|}
\hline CROP & STRIP(S) & ACRES & NOTES \\
\hline Safflower (SAF) & 10 & 13.76 & RWW cover crop \\
\hline Lentils (LTL) & $1,6,11$ & 40.65 & \\
\hline Rye (RYE) & 4,9 & 27.81 & No-tilled into bladed CV \\
\hline Chickling Vetch (CV) & $3,8,13,16,18,21$ & 68.58 & $\begin{array}{c}13,16,18,21 \text { RWW cover crop } \\
3,8,13 \text { Manure }\end{array}$ \\
\hline Khorasan Wheat (KW) & $\begin{array}{c}2,5,7,12,14,15,17 \mathrm{~N} \\
17 \mathrm{~S}, 19,20\end{array}$ & 115.91 & $\begin{array}{c}2,7,12 \\
\text { Under-seeded with Sweet Clover } \\
20 \sim 3 \text { acres finished with BW }\end{array}$ \\
\hline \multicolumn{3}{|c|}{ TOTAL CROP ACRES: } & 266.71 \\
\hline \multicolumn{3}{|c|}{ CRP } & 22.87 \\
\hline \multicolumn{3}{|c|}{ Border Strips (non-crop): } & 27.87 \\
\hline \multicolumn{3}{|c|}{ TOTAL FIELD ACRES: } & 317.45 \\
\hline
\end{tabular}


Field II: 488.51 acres

FSA Farm / Tract Numbers: 5528 -8251

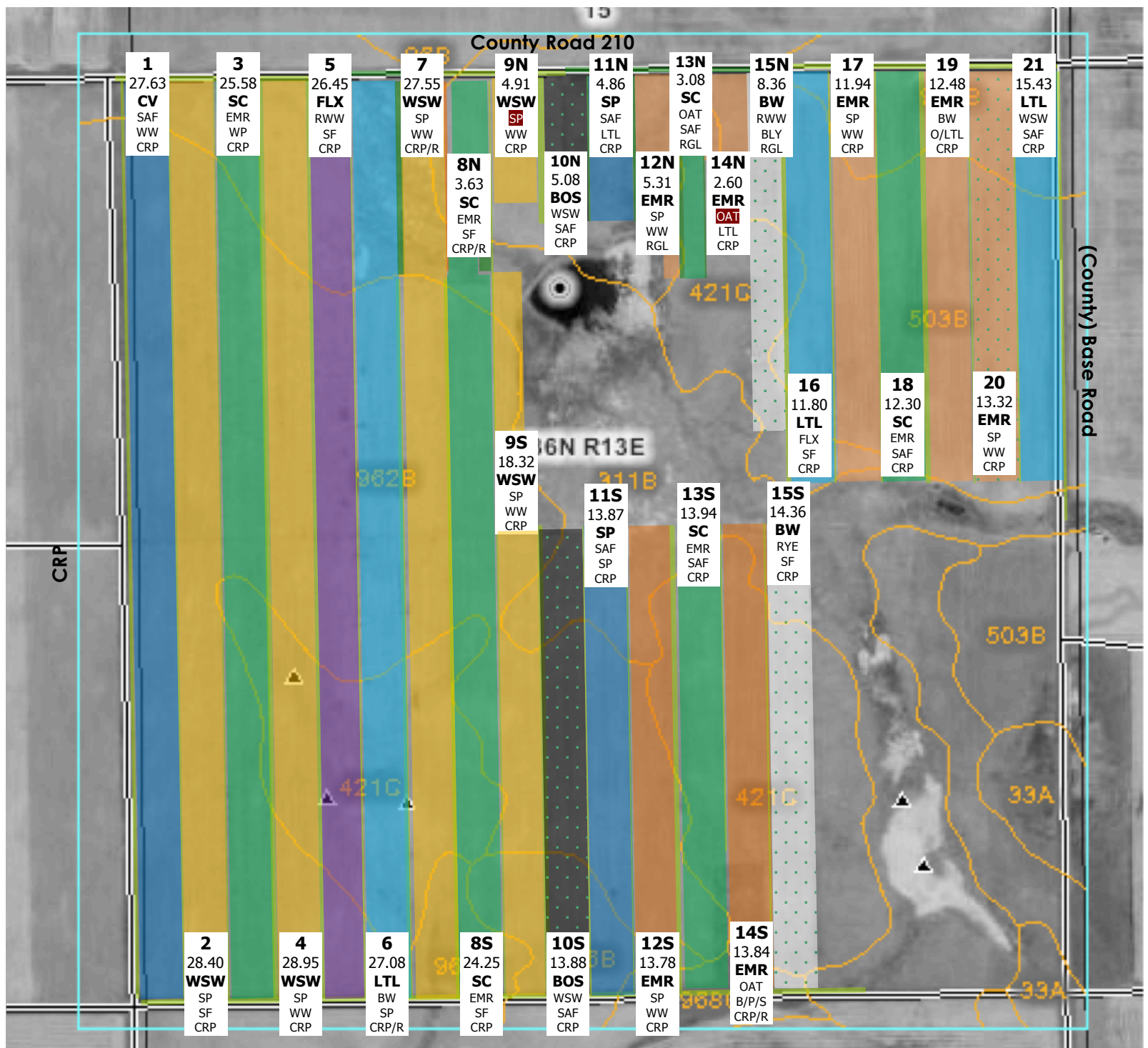

\begin{tabular}{|c|c|c|c|}
\hline CROP & STRIP(S) & ACRES & NOTES \\
\hline Flax (FLX) & 5 & 26.45 & \\
\hline Black Oil Sunflower (BOS) & $10 \mathrm{~N}, 10 \mathrm{~S}$ & 18.96 & \\
\hline Buckwheat (BW) & $15 \mathrm{~N}, 15 \mathrm{~S}$ & 22.72 & RWW Cover Crop \\
\hline Lentils (LTL) & $6,16,21$ & 54.31 & \\
\hline Spring Peas (SP) & $11 \mathrm{~N}, 11 \mathrm{~S}$ & 18.73 & \\
\hline Chickling Vetch (CV) & 1 & 27.63 & Green manure \\
\hline White Spring Wheat(WSW) & $2,4,7,9 \mathrm{~N}, 9 \mathrm{~S}$ & 108.13 & \\
\hline Emmer (EMR) & $12 \mathrm{~N}, 12 \mathrm{~S}, 14 \mathrm{~N}, 14 \mathrm{~S} 17,19$, & 73.27 & $\begin{array}{l}20 \text { RWW Cover Crop;12N, 12S, } 17 \\
\text { Under-seeded with Sweet Clover }\end{array}$ \\
\hline Sweet Clover (SC) & $3,8 \mathrm{~N}, 8 \mathrm{~S}, 13 \mathrm{~N}, 13 \mathrm{~S}, 18$ & 82.78 & Green Manure; Apply manure \\
\hline \multicolumn{3}{|c|}{ TOTAL CROP ACRES: } & 61 \\
\hline \multirow{2}{*}{\multicolumn{3}{|c|}{$\begin{array}{r}\text { CRP } \\
\text { Border Strips (non-crop): }\end{array}$}} & 45.58 \\
\hline & & & 9.92 \\
\hline \multicolumn{3}{|c|}{ TOTAL FIELD ACRES: } & 488.48 \\
\hline
\end{tabular}


Field IV: 38.74 acres

FSA Farm / Tract Numbers: 5528 -8251

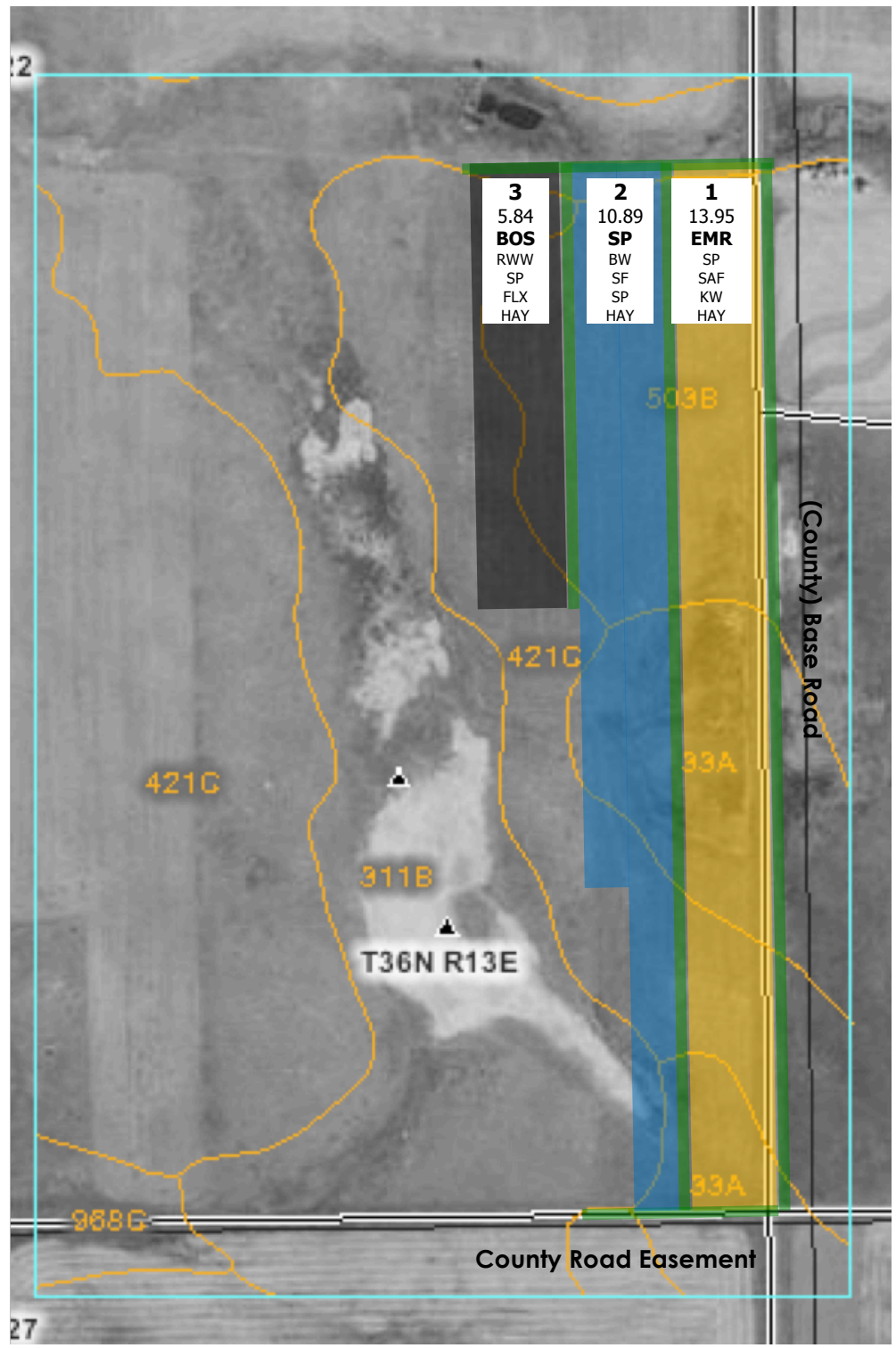

\begin{tabular}{|c|c|c|c|}
\hline CROP & STRIP & ACRES & NOTES \\
\hline Emmer (EMR) & 1 & 13.95 & $\begin{array}{c}\text { Under-seeded with Sweet Clover } \\
\sim 3 \text { acres to be seeded to saline- } \\
\text { tolerant sod mix }\end{array}$ \\
\hline Spring Peas (SP) & 2 & 10.89 & $\begin{array}{r}\sim 2 \text { acres to be seeded to saline- } \\
\text { tolerant sod mix }\end{array}$ \\
\hline Black Oil Sunflower (BOS) & 3 & 5.84 & $\mathbf{5}$ \\
\hline \multicolumn{3}{|r|}{ TOTAL CROP ACRES: } & 8.06 \\
\hline \multicolumn{3}{r|r|}{ Border Strips (non-Crop): } & $\mathbf{3 8 . 7 4}$ \\
\hline
\end{tabular}


Field V: 238.37 acres

FSA Farm / Tract Numbers: 5528 -799

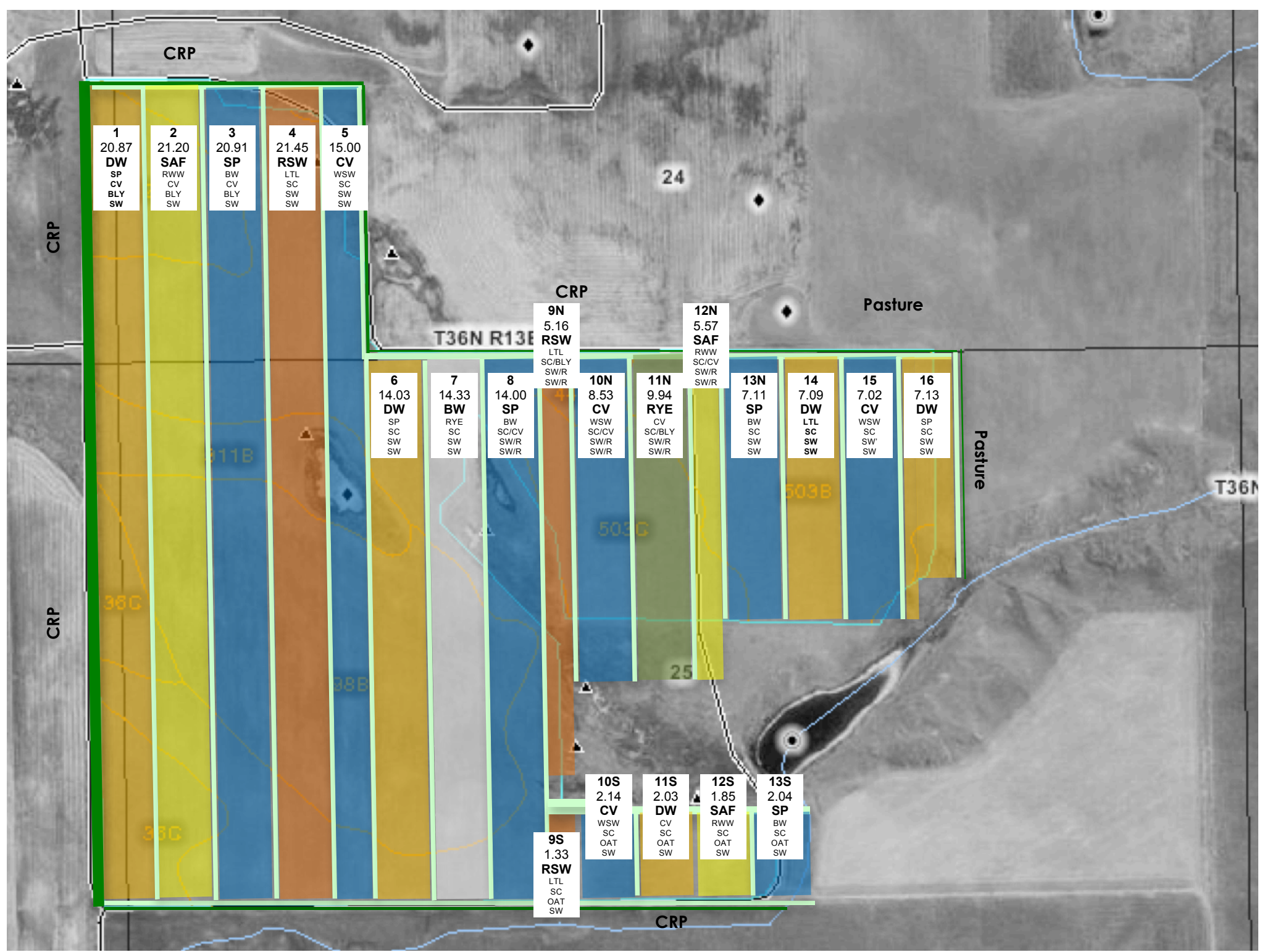

\begin{tabular}{|c|c|c|c|}
\hline CROP & STRIP(S) & ACRES & NOTES \\
\hline Spring Peas (SP) & $3,8,13 \mathrm{~N}, 13 \mathrm{~S}$ & 44.06 & \\
\hline Chickling Vetch & $5,10 \mathrm{~N}, 10 \mathrm{~S}, 15$ & 32.69 & Green manure \\
\hline Durum (DW) & $1,6,14,16$ & 51.15 & \\
\hline Red Spring Wheat (RSW) & $4,9 \mathrm{~N}, 9 \mathrm{~S}$ & 27.94 & \\
\hline Rye (RYE) & $11 \mathrm{~N}$ & 9.94 & No-tilled into (bladed) CV \\
\hline Buckwheat (BW) & 7 & 14.33 & \\
\hline Safflower (SAF) & $2,12 \mathrm{~N}, 12 \mathrm{~S}$ & 28.62 & \\
\hline \multicolumn{3}{|c|}{ TOTAL CROP ACRES: } & 0 \\
\hline \multirow{2}{*}{\multicolumn{3}{|c|}{$\begin{array}{l}\text { Border Strips (non-crop): } \\
\text { TOTALFIELD ACRES: }\end{array}$}} & 29.64 \\
\hline & & & 29.64 \\
\hline
\end{tabular}


Field VII: 37.54 acres

FSA Farm / Tract Numbers: 5528-799

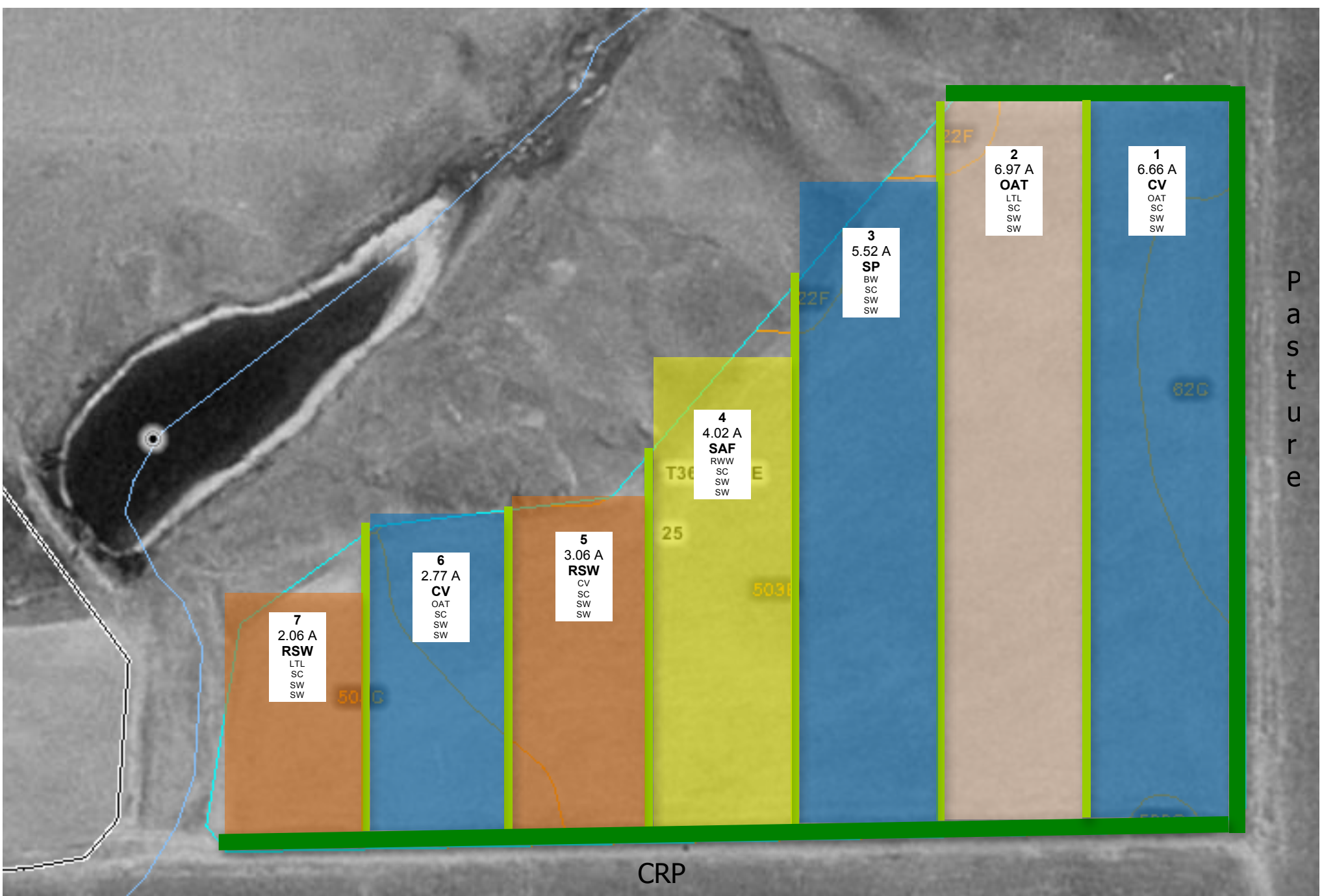

\begin{tabular}{|c|c|c|c|}
\hline CROP & STRIP(S) & ACRES & NOTES \\
\hline Oats (OAT) & 2 & 6.97 & \\
\hline Red Spring Wheat (RSW) & 5,7 & 5.12 & \\
\hline Spring Peas (SP) & 3 & 5.52 & Green manure \\
\hline Chickling Vetch (CV) & 1,6 & 9.43 & $\mathbf{0}$ \\
\hline Safflower (SAF) & 4 & 4.02 & 6.48 \\
\hline & TOTAL CROP ACRES: & $\mathbf{6 . 4 8}$ \\
\hline
\end{tabular}




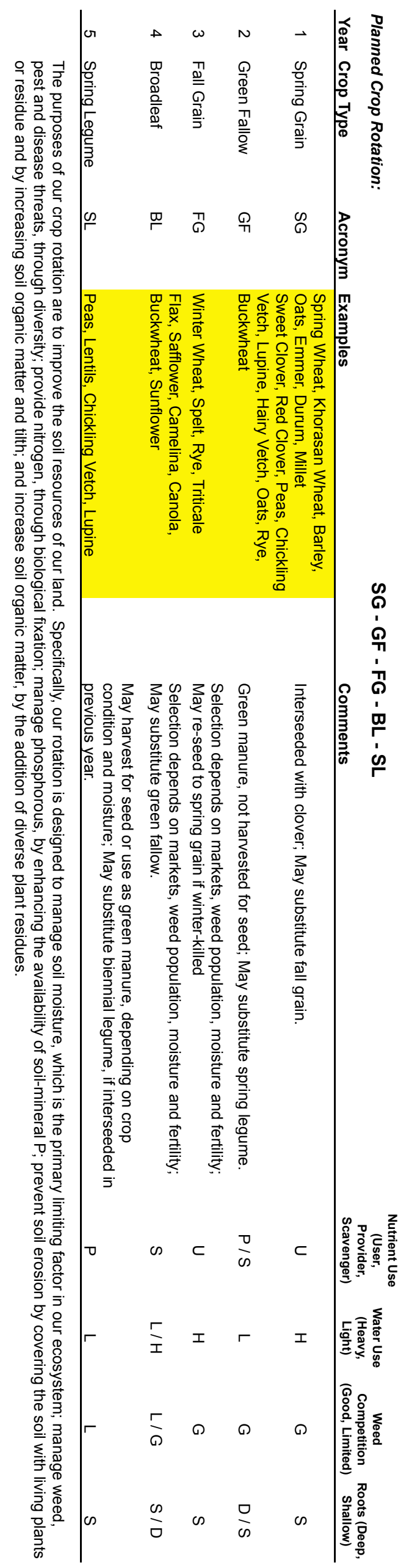




\section{Appendix 2: Interview and Survey Guides}

I completed in-depth interviews with 25 growers (including 10 who were not currently contracting with the values-based supply chain, but had either done so in the past or had collaborated with VBSC members on field trials, production, or marketing), 15 other members of the supply chain (processors, processing plant workers, buyers, investors and board members) and 12 technical assistance personnel (university researchers, county extension agents, experiment station staff, federal conservation agency employees, organic inspectors, and nonprofit staff. Seven of the current VBSC growers also responded to the survey included in this appendix.

\section{Interview Guide for Diversified Farmers on the Northern Great Plains \\ Liz Carlisle \\ UC Berkeley, 2012}

\section{Farming \& learning background}

1. When and how did you learn to farm/ranch? What person or organization, if any, helped you the most?

2. How did you first learn about Timeless/Kamut/Farmer Direct Co-operative? What made you want to grow for them and when did you start?

3. Do you or your family have a background in conventional commodity production? If so, can you describe your transition to the farming practices you use now?

4. How many generations of your family have been involved in farming, ranching, or rural community work? Do you draw inspiration from your parents, grandparents or other family members in pursuing agriculture the way you do?

5. What is the most valuable lesson you've learned in running this type of farm/ranch? 
6. In your experience so far growing for Kamut/Timeless/Farmer Direct, what obstacle or situation has posed the largest challenge? How did you meet this challenge, and what did you learn from overcoming it?

\section{Farm management \& philosophy}

1. Do you have any farm/ranch partners helping you? Who are they, and how are the types of work distributed?

\begin{tabular}{|l|l|l}
\hline Farming Partner Name & Specialty & Comments \\
\hline & & \\
\hline & & \\
\hline & & \\
\hline & & \\
\hline & & \\
\hline
\end{tabular}

2. Why do you farm/ranch like you farm/ranch? What are your goals? (general philosophy)?

3. How do you describe the added value of the products you produce: (environmental benefits, health benefits, taste, support rural livelihoods and community)

4. Personally, do you see your choice to farm/ranch this way more as an economic decision, an environmental decision, part of a social movement, or some combination?

5. How did you get access to the land you're currently using?

\section{Information, networks, and research}

1. Which of the following best supports you/holds you accountable to your sustainable farming/ranching practices (duplicate question from survey):

- Price premium

- Organic certification/organic certifier

- GMO free certification/GMO-free certifier

- Timeless Foods, Kamut, or Farmer Direct Cooperative

- Other buyers

- Trademark protection/license

- Formal farmer/rancher organization (like the Farm Bureau)

- Formal farmer/rancher network or nonprofit (like AERO, NPSAS, SOG)

- Informal networks and neighbors

- Consumers 
- Family members (including past experience)

- Conservation or other incentive programs offered by state, provincial, or national governments

- Environmental regulations or other policies enforced by state, provincial, or national governments

- Technical assistance providers associated with the government, university, or extension

- Experience with cooperative activities or associations

- Personal values

- Other

2. How do you view the tension of cooperating with other alternative farmers/ranchers, but also competing with them for consumers' food dollars?

3. Tell me about your relationships with local universities and extension.

4. What research topics and research designs (randomized split block v. whole field comparisons) would be the most useful for your operation?

\begin{tabular}{|l|l|l}
\hline Kind of Research & Who would do it? & Comments \\
\hline & & \\
\hline & & \\
\hline & & \\
\hline & & \\
\hline & & \\
\hline
\end{tabular}

5.Have you participated in any on-farm/on-ranch research, conducted by yourself or others? 


\section{Energetics and environment}

1. What practices do you do that you think are most beneficial to the environment? Do these make sense in terms of profitability?

\begin{tabular}{|l|l|l}
\hline Practice & Profitable $(\mathrm{Y} / \mathrm{N})$ & Comments \\
\hline & & \\
\hline & & \\
\hline & & \\
\hline & & \\
\hline & & \\
\hline
\end{tabular}

2. Do you use crop/livestock rotations or rotational grazing? Can you describe the rotation you use? Why do you rotate (fertility, break pest/disease cycles, variety of crops)?

3. Do you use any intercropping or undersowing practices? Can you describe them and explain why you use them?

4.Do you use cover crops or green manures? Which ones and for what purposes? Which crops do you rotate them with and on what schedule (when do you seed the cover crop, when do you incorporate it?)

5. What non-crop plants and animals do you intentionally or unintentionally support with your farming/ranching system and practices (pests, beneficial organisms, pollinators, wildlife)?

6. If you were to step back and view your operation from field to final point-of-sale, which parts are most problematic environmentally? 


\section{Farm finances \& local economies}

1. How do you price the products you direct market? How do you decide if you need to change the price?

2. Including Kamut/Timeless/Farmer Direct, what marketing channels do you use? Can you estimate the percentage of sales from each?

\begin{tabular}{|l|l|l}
\hline Marketing Channel & Percentage of Sales & Comments \\
\hline & & \\
\hline & & \\
\hline & & \\
\hline & & \\
\hline & & \\
\hline
\end{tabular}

3. Do you grow any food for yourself and your family on your farm/ranch? About how much (relative to your total food needs)? What are the main benefits (financial, health, educational, taste, etc.)

4. What were your farm/ranch's gross annual sales in 2009? What about net profit in 2009 ?

5. Approximately what percentage of this economic activity is from Timeless/Kamut/Farmer-Direct?

6. Compare your returns from before entering the Timeless/Kamut/Farmer Direct market to those you've earned since you began this contracting relationship. Are there advantages and disadvantages to each market?

7. Do you work together with other farms/ranches (in or outside of Timeless/Kamut/Farmer Direct) in production, marketing, distribution, or other efforts? 
8. What have been the toughest times for you as a farmer/rancher? Do you feel like participation in this value chain helps you weather economic and environmental crises more effectively? Are there other aspects of your approach to farming/ranching that make your farm and business more resilient?

\section{Health Insurance}

1. Do you have health insurance coverage?

2. If so, do you:

- Purchase it on the private market

- Get it from an off-farm job (yourself or your spouse's)

- Qualify for Canadian state health insurance, Medicare, Medicaid, or other government programs

3. What percent of your income, approximately, do you use to pay for health care?

4. Has your health care coverage status impacted your decisions about your farming operation (eg decision to take an off-farm job, decision to encourage children to find offfarm jobs, financially conservative decision-making in order to save money for potential health emergency, inability to work due to health conditions that could have been prevented had you been able to afford medical care)

5. How important do you think health care coverage is for your farming/ranching community more generally?

6. How would you describe the health care policy you support? (eg government sponsored single-payer plan, employer-based system with government-sponsored options for those who "fall through the cracks", employer-based system only (with self-employed purchasing on the private market), fully private and individual health insurance market (eg medical savings accounts) 


\section{Labor}

1. To what extent do you use volunteers on the farm/ranch? [interns, apprentices, CSA members]

2. Do you hire seasonal or temporary workers? How do you hire them, and when?

3. Are there labor laws that affect your use of volunteers? How about permanent and temporary workers?

4. What are all the positions that workers have on your farm/ranch? [Fill in the list below. For each of the following positions in the table ask the following questions:] How many did you employ in 2011? What are their wage or salary rates? What benefits do they receive?

\begin{tabular}{|l|l|l|l}
\hline Position & \# in 2011 & wage/salary & benefits [health care, housing, free veggies] \\
\hline Interns & & & \\
\hline Apprentices & & & \\
\hline $\begin{array}{l}\text { Seasonal } \\
\text { farmworkers/ranch } \\
\text { hands }\end{array}$ & & & \\
\hline $\begin{array}{l}\text { Permanent } \\
\text { farmworkers/ranch } \\
\text { hands }\end{array}$ & & & \\
\hline
\end{tabular}

5. How do you and your farm/ranch partners value your own time spent working on the farm/ranch? 


\section{Final questions}

1. Are there any specific political or community issues affecting Timeless/Kamut/Farmer Direct farmers/ranchers that are especially popular or controversial right now? Is there a group or organization that you're working through to address these issues?

2. What advice would you give to young farmers/ranchers who are looking to get into sustainable or diversified farming or ranching?

3. Is there anything else I should have asked you?

4. May I contact you by phone/email if I have any follow up questions? 


\section{Diversified Farming and Ranching on the Northern Great Plains}

Thank you for agreeing to participate in my study! This survey is part of my dissertation project on diversified farming systems on the Northern Great Plains. After completion of the survey, I will meet with you to ask more in-depth questions about your operation and your experiences and perspectives.

This survey should take about 15-25 minutes to complete. Your responses in the survey are confidential, and I do VERY much appreciate your participation. I know you are busy.

1. How many partners manage your farm or ranch? Farm/ranch partners are those people who you consider to be essential players in farm management and/or operations.

Number of partners:

2. How many acres is your farm/ranch? This should include acreage of all fields in your farming operation

Acreage: 


\section{Diversified Farming and Ranching on the Northern Great Plains}

\section{Of the total acres in your farming/ranching operation at the end of the 2011 growing}

\section{season, how many were:}

Owned?

Rented or leased public

(government) land

Rented or leased from a

private landowner

Leased for oil or gas

development

Leased for wind or solar

development

Leased to a

telecommunications

company

Accessible to hunters (with

or without a fee)

Cropland?

Rangeland or pasture?

In field borders, grassed

waterways, buffers,

woodland, forest, or other

areas associated with

conservation practices but

not cropped?

Cropland planted to overwintering plants - winter grains, perennial forages and annual cover crops (crops not harvested) or green manure crops (nitrogen-fixing cover crops)?

Certified for organic production?

Enrolled in the Conservation Reserve Program (CRP), the Wetland Reserve Program (WRP), the Conservation Stewardship Program (CSP), the Environmental Quality Incentives Program (EQIP) or similar program?

Covered by a conservation easement?
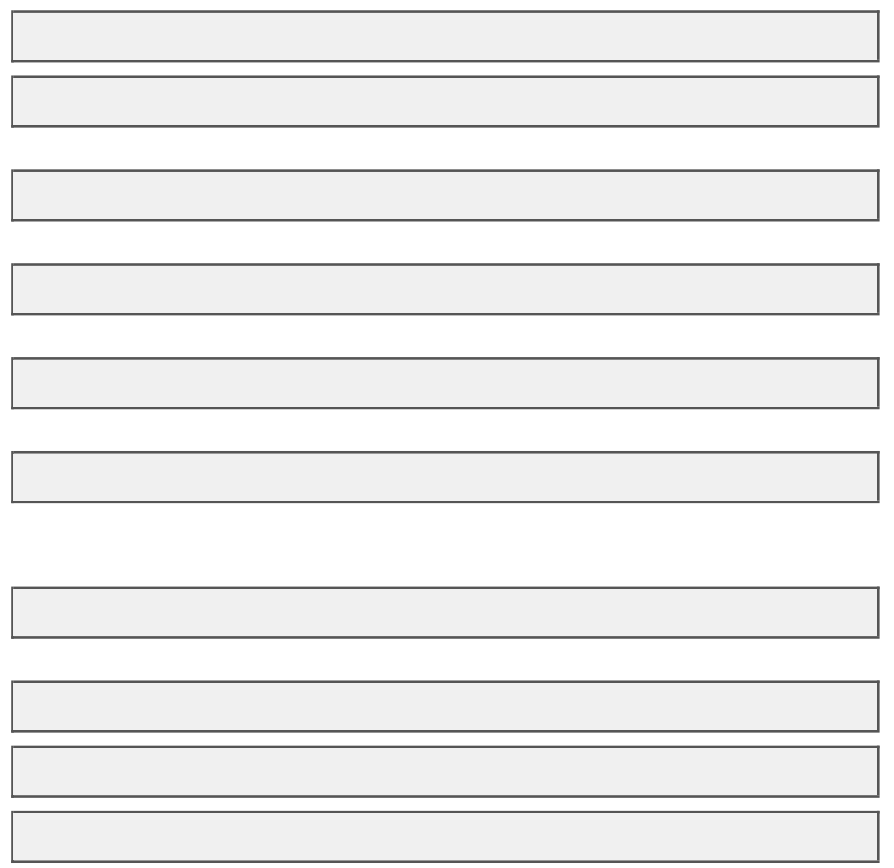

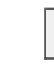

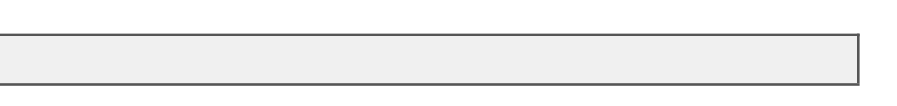




\section{Diversified Farming and Ranching on the Northern Great Plains}

4. If you rent or lease land or are loaned land by a relative or friend, please briefly specify your arrangement (e.g., cash rent at normal rental value, loaned from a family member, pay property taxes as rent, etc.)

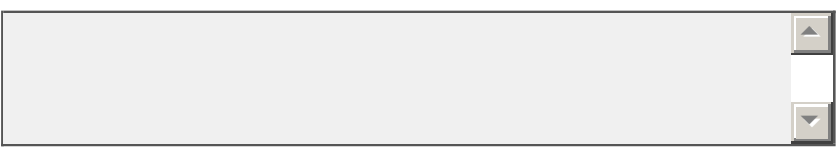

\section{Of the cropland you farmed in 2011, how many acres were:}
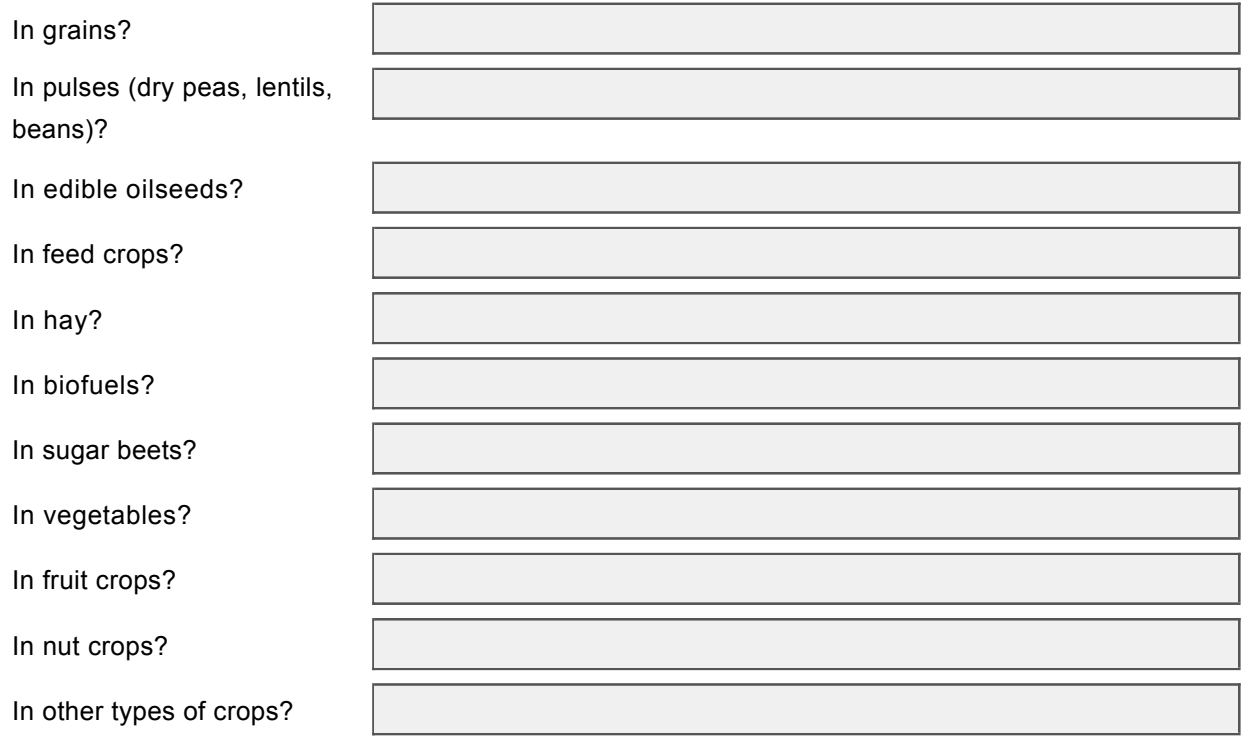

6. Approximately how many CROPS within the following crop types do you produce over the course of a year? For example, growing barley and wheat would count as 2 grain crops.

Grains?

Pulses (dry peas, lentils,

beans)?

Edible oilseeds?

Feed crops?

Hay?

Biofuels?

Sugar beets?

Vegetables?

Fruit crops?

Nut crops?

Other types of crops?

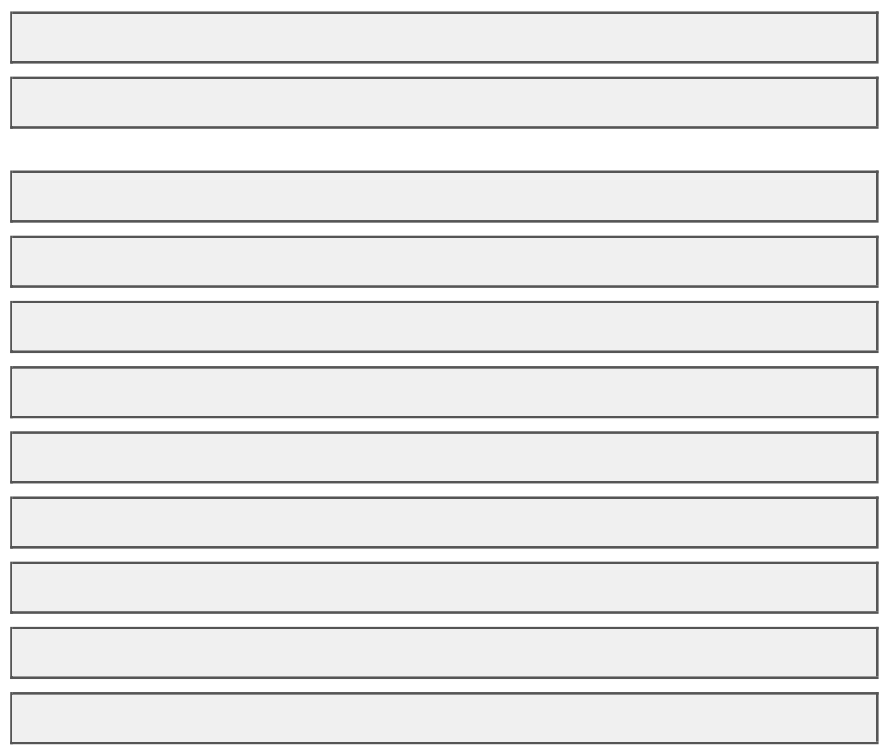




\section{Diversified Farming and Ranching on the Northern Great Plains}

7. Approximately how many VARIETIES within the following crop types do you produce over the course of a year? For example, growing black beluga lentils, du puy lentils, and chickpeas would count as 3 varieties of pulse crops.

Grains?

Pulses (dry peas, lentils,

beans)?

Edible oilseeds?

Feed crops?

Hay?

Biofuels?

Sugar beets?

Vegetables?

Fruit crops?

Nut crops?

Other types of crops?

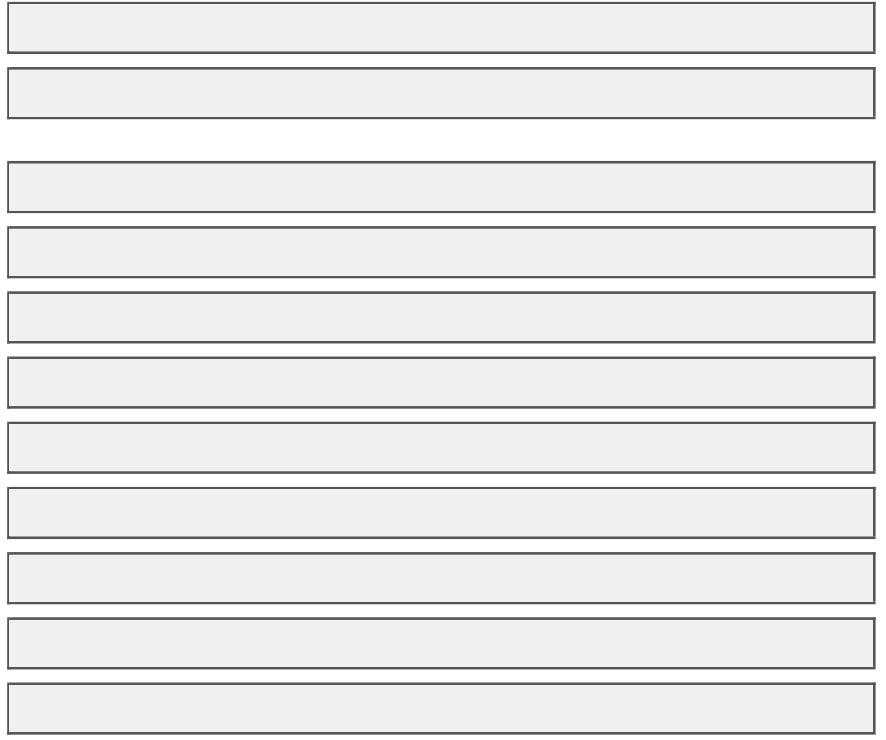

8. List the cover crops or green manure crops you use, if any:

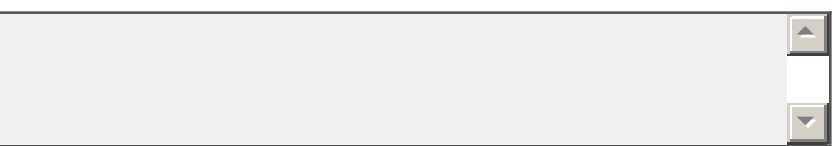

9. In what year did you begin growing for Timeless Seeds, Kamut, Inc., and/or Farmer Direct Co-operative? (Leave line blank if you do not grow for this company/cooperative).

Kamut

Timeless

Farmer Direct

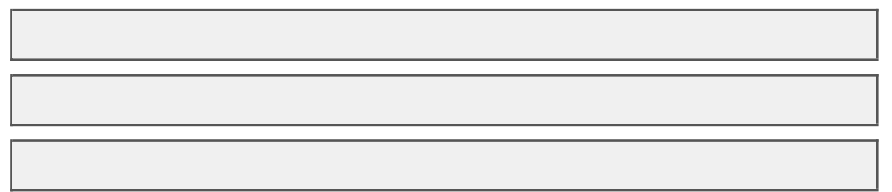




\section{Diversified Farming and Ranching on the Northern Great Plains}

10. Are you certified organic?

Y Yes

No

Some of my land is, but not all of it

If yes, what year were you certified? If not, do your practices follow the organic standard or differ from it in important ways?

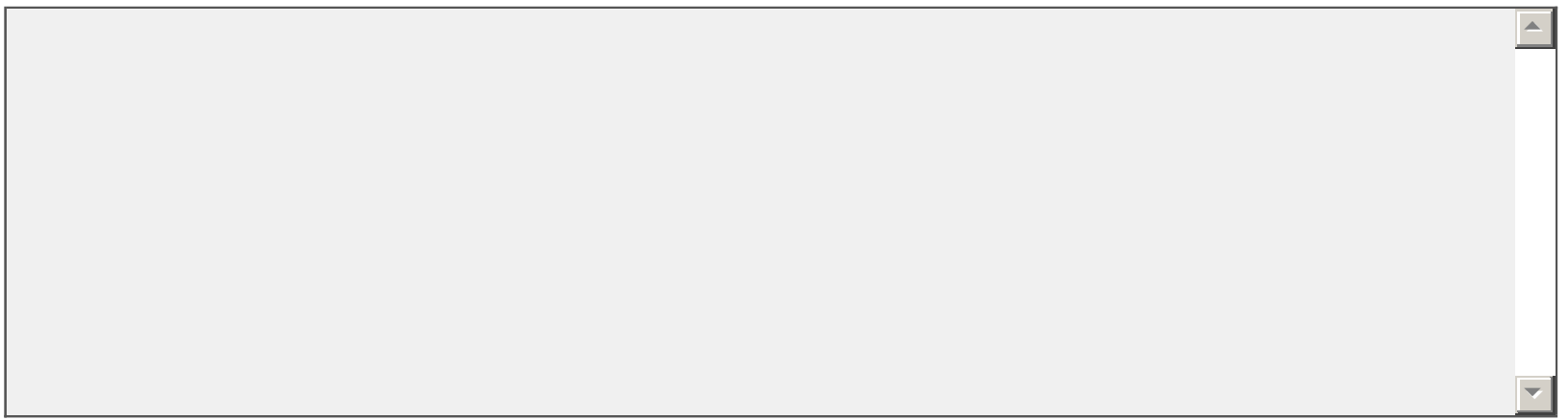

11. In 2011 did you use any sources of credit, such as a production loan?

Y Yes

No

If yes, please specify which sources:

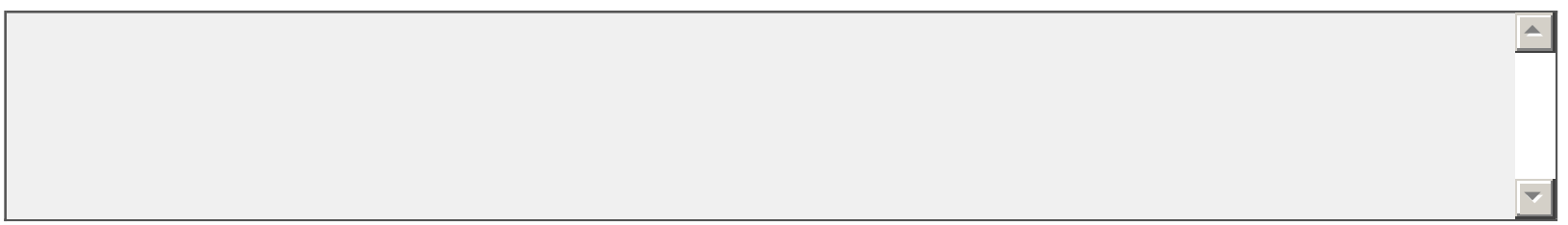

12. Do you have any farm/ranch animals?

Y Yes

No 


\section{Diversified Farming and Ranching on the Northern Great Plains}

13. How many different SPECIES of livestock do you have? (For example, cattle, bison, and chickens count as 3 species)

Number of species

14. How many different BREEDS/VARIETIES of livestock do you have? (For example criollo cattle, white angus cattle, black angus cattle, and bison count as $\mathbf{4}$ breeds)

Number of breeds/varieties

15. Do you have any minor or heritage breed animals?

Y Yes

No

16. For each of the following types of livestock, please indicate the total number SOLD in 2011

Chickens (layers)

Chickens (broilers)

Other poultry

Hogs and pigs

Sheep and lambs

Goats and kids

Dairy cattle (cows, heifers,

steers, calves, bulls)

Beef cattle (cows, heifers,

steers, calves, bulls)

Bison

Llamas or alpacas

Other

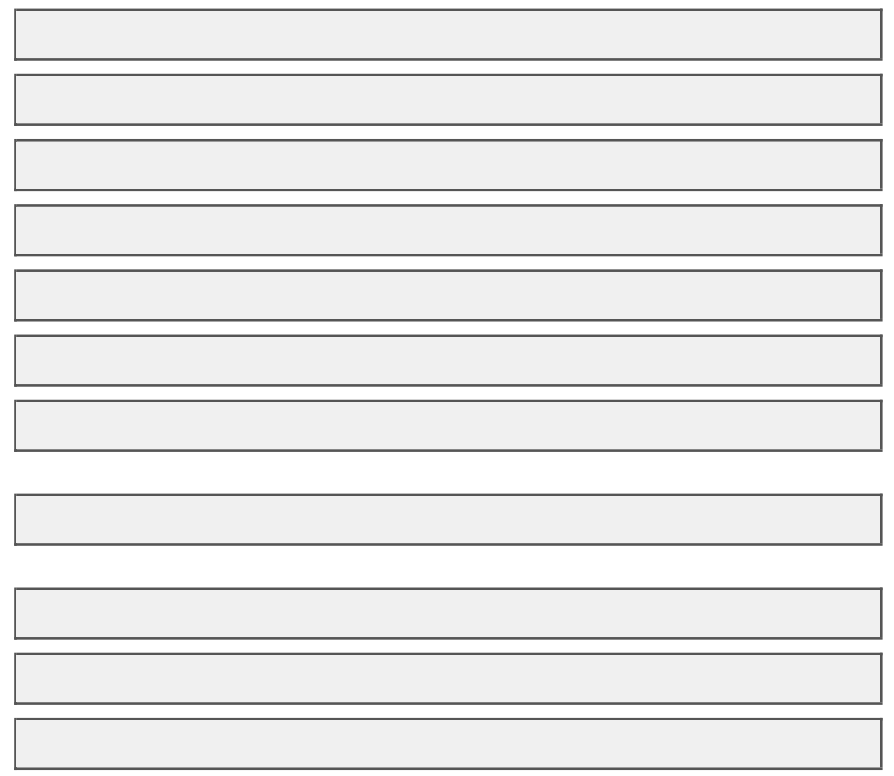




\section{Diversified Farming and Ranching on the Northern Great Plains}

17. For each of the following types of livestock, please indicate the total number ON HAND at the end of 2011
Chickens (layers)
Chickens (broilers)
Other poultry
Hogs and pigs
Sheep and lambs
Goats and kids
Dairy cattle (cows, heifers,
steers, calves, bulls)
Beef cattle (cows, heifers,
steers, calves, bulls)
Bison
Llamas or alpacas
Other
18. Do you have any draft animals?
C Yes
No

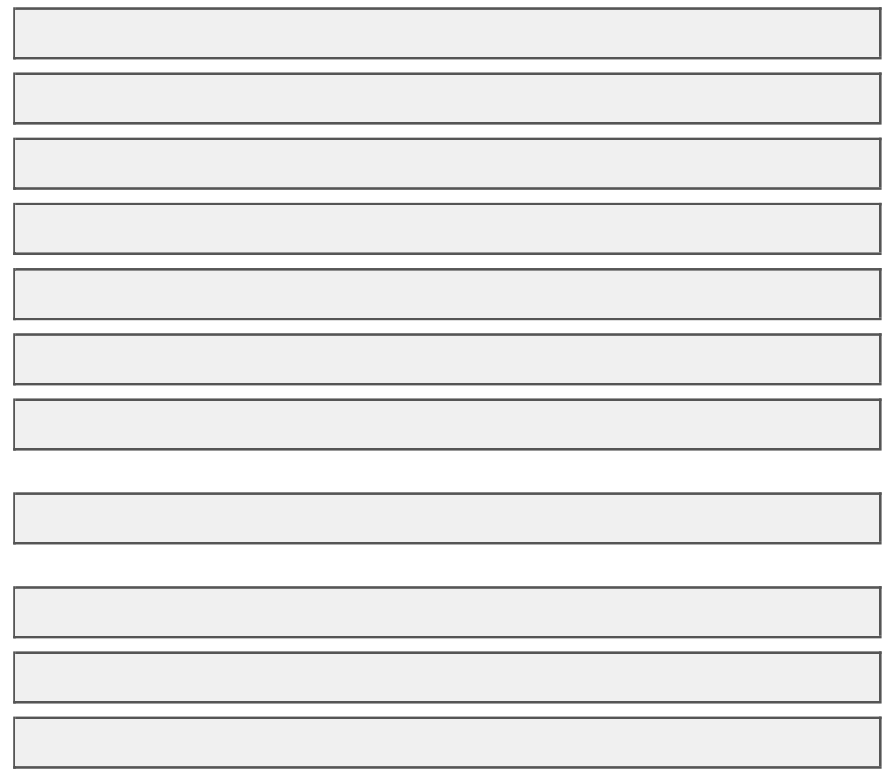

Please specify type and number:

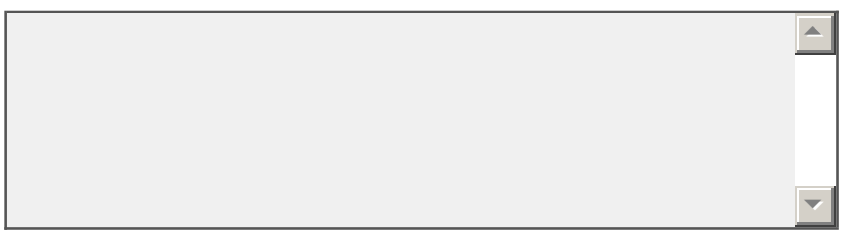




\section{Diversified Farming and Ranching on the Northern Great Plains}

19. Which of the following best SUPPORT you in your sustainable farming/ranching practices? Please rate the level of importance of each potential source of support below:

\begin{tabular}{|c|c|}
\hline & None or N/A \\
\hline Price premium & 0 \\
\hline $\begin{array}{l}\text { Organic } \\
\text { certification/organic certifier }\end{array}$ & 0 \\
\hline $\begin{array}{l}\text { GMO free } \\
\text { certification/GMO-free } \\
\text { certifier }\end{array}$ & 0 \\
\hline $\begin{array}{l}\text { Timeless Foods, Kamut, or } \\
\text { Farmer Direct Cooperative }\end{array}$ & 0 \\
\hline Other buyers & 0 \\
\hline $\begin{array}{l}\text { Trademark } \\
\text { protection/license }\end{array}$ & 0 \\
\hline
\end{tabular}

Formal farmer/rancher organization (like the Farm

Bureau)

Formal farmer/rancher network or nonprofit (like AERO, NPSAS, SOG)

Informal networks and neighbors

Consumers

Family members (including past experience)

Conservation or other incentive programs offered by state, provincial, or national governments

Environmental regulations or other policies enforced by state, provincial, or national governments

Technical assistance providers associated with the government, university, or extension

\section{Experience with} cooperative activities or associations

Personal values

Other (please specify below)

Low

Moderate

High

0

O

O

○

C

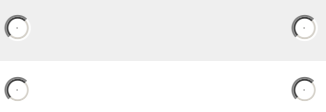

O

○

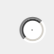

O

○

c

○

○

O

○

O

0

Very High

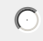

○

○

C

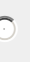$$
\text { O }
$$

0

0

0

○

0

C

o 0

C

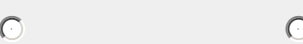

C

c

C

○

C

C

o 


\section{Diversified Farming and Ranching on the Northern Great Plains}

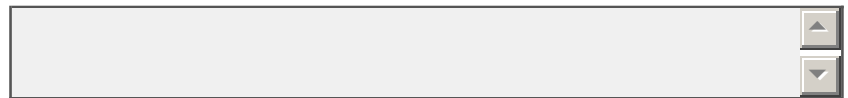

\section{Which of the following best HOLD YOU ACCOUNTABLE to your sustainable}

farming/ranching practices? Please rate the level of importance of each potential source of accountability below:

\begin{tabular}{|c|c|c|c|c|c|}
\hline & None or N/A & Low & Moderate & High & Very High \\
\hline Price premium & 0 & 0 & 0 & 0 & 0 \\
\hline $\begin{array}{l}\text { Organic } \\
\text { certification/organic certifier }\end{array}$ & 0 & 0 & 0 & 0 & 0 \\
\hline $\begin{array}{l}\text { GMO free } \\
\text { certification/GMO-free } \\
\text { certifier }\end{array}$ & 0 & 0 & 0 & 0 & 0 \\
\hline $\begin{array}{l}\text { Timeless Foods, Kamut, or } \\
\text { Farmer Direct Cooperative }\end{array}$ & 0 & 0 & 0 & 0 & 0 \\
\hline Other buyers & 0 & 0 & 0 & 0 & 0 \\
\hline $\begin{array}{l}\text { Trademark } \\
\text { protection/license }\end{array}$ & 0 & 0 & 0 & 0 & 0 \\
\hline $\begin{array}{l}\text { Formal farmer/rancher } \\
\text { organization (like the Farm } \\
\text { Bureau) }\end{array}$ & 0 & 0 & 0 & 0 & 0 \\
\hline $\begin{array}{l}\text { Formal farmer/rancher } \\
\text { network or nonprofit (like } \\
\text { AERO, NPSAS, SOG) }\end{array}$ & 0 & 0 & 0 & 0 & 0 \\
\hline $\begin{array}{l}\text { Informal networks and } \\
\text { neighbors }\end{array}$ & 0 & 0 & 0 & 0 & 0 \\
\hline Consumers & 0 & 0 & 0 & 0 & 0 \\
\hline $\begin{array}{l}\text { Family members (including } \\
\text { past experience) }\end{array}$ & 0 & 0 & 0 & 0 & 0 \\
\hline $\begin{array}{l}\text { Conservation or other } \\
\text { incentive programs offered } \\
\text { by state, provincial, or } \\
\text { national governments }\end{array}$ & 0 & 0 & 0 & 0 & 0 \\
\hline $\begin{array}{l}\text { Environmental regulations } \\
\text { or other policies enforced } \\
\text { by state, provincial, or } \\
\text { national governments }\end{array}$ & 0 & 0 & 0 & 0 & 0 \\
\hline $\begin{array}{l}\text { Technical assistance } \\
\text { providers associated with } \\
\text { the government, university, } \\
\text { or extension }\end{array}$ & 0 & 0 & 0 & 0 & 0 \\
\hline $\begin{array}{l}\text { Experience with } \\
\text { cooperative activities or } \\
\text { associations }\end{array}$ & 0 & 0 & 0 & 0 & 0 \\
\hline Personal values & 0 & 0 & 0 & 0 & 0 \\
\hline $\begin{array}{l}\text { Other (please specify } \\
\text { below) }\end{array}$ & 0 & 0 & 0 & 0 & 0 \\
\hline
\end{tabular}




\section{Diversified Farming and Ranching on the Northern Great Plains}

Other:

21. Consider the people who provide information to you to help you manage your operation. Please rate the level of importance of each potential information source below

\begin{tabular}{|c|c|c|c|c|}
\hline & None & Low & Moderate & High \\
\hline $\begin{array}{l}\text { Other } \\
\text { Timeless/Kamut/Farmer } \\
\text { Direct farmers }\end{array}$ & 0 & 0 & 0 & 0 \\
\hline $\begin{array}{l}\text { Other farmers outside } \\
\text { Timeless/Kamut/Farmer } \\
\text { Direct }\end{array}$ & 0 & 0 & 0 & 0 \\
\hline $\begin{array}{l}\text { Cooperative extension } \\
\text { specialists }\end{array}$ & 0 & 0 & 0 & 0 \\
\hline $\begin{array}{l}\text { Conservation agents (such } \\
\text { as NRCS) }\end{array}$ & 0 & 0 & 0 & 0 \\
\hline $\begin{array}{l}\text { Independent agricultural } \\
\text { consultants }\end{array}$ & 0 & 0 & 0 & 0 \\
\hline $\begin{array}{l}\text { Fertilizer/input dealers or } \\
\text { sales representatives }\end{array}$ & 0 & 0 & 0 & 0 \\
\hline $\begin{array}{l}\text { Farmworkers or interns on } \\
\text { your farm }\end{array}$ & 0 & 0 & 0 & 0 \\
\hline $\begin{array}{l}\text { Formal farmer organization } \\
\text { (like the Farm Bureau) }\end{array}$ & 0 & 0 & 0 & 0 \\
\hline $\begin{array}{l}\text { Formal farmer network or } \\
\text { nonprofit (like AERO, } \\
\text { NPSAS, SOG) }\end{array}$ & 0 & 0 & 0 & 0 \\
\hline $\begin{array}{l}\text { Other (please specify } \\
\text { below) }\end{array}$ & 0 & 0 & 0 & 0 \\
\hline
\end{tabular}

22. What forms of communication do you use most in the social networks specified above? Please rate the level of importance of each communication method below

$\begin{array}{lccccc} & \text { None } & \text { Low } & \text { Moderate } & \text { High } & 0 \\ \text { In person conversations } & 0 & 0 & 0 & 0 & 0 \\ \text { Phone conversations } & 0 & 0 & 0 & 0 & 0 \\ \text { Email } & 0 & 0 & 0 & 0\end{array}$

Other: 


\section{Diversified Farming and Ranching on the Northern Great Plains}

23. Consider how you access information about managing your operation from sources other than your social networks. Please rate the level of importance of each potential information source below:

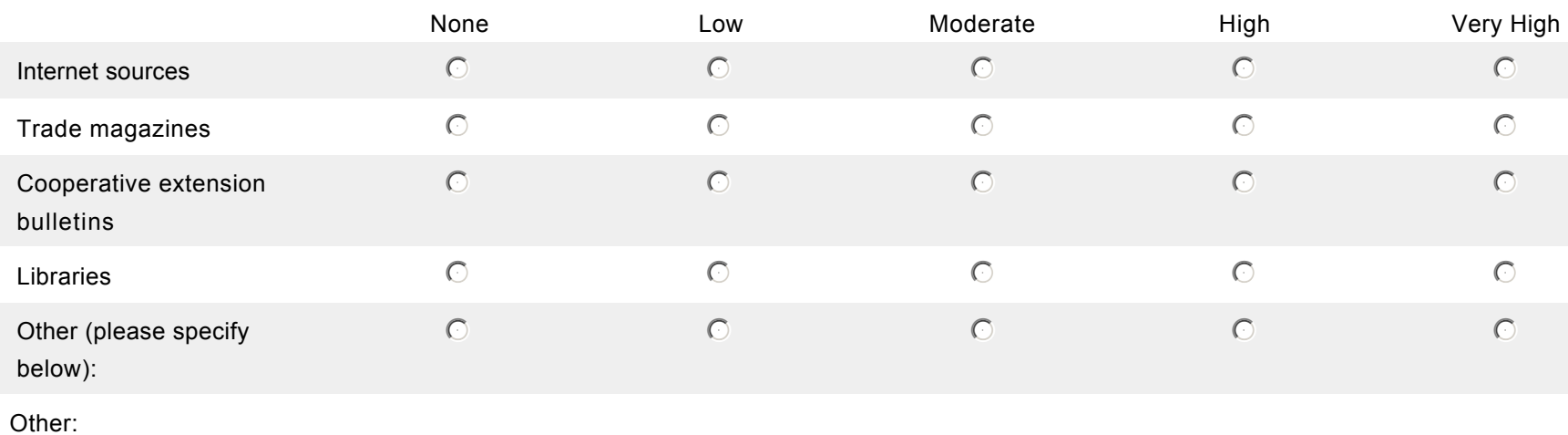

24. Please share the three websites that you consider most important for information on managing your operation

Website \#1

Website \#2

Website \#3

25. Do you have any renewable electricity generation on your farm, such as a wind generator, solar photovoltaic panels, or methane capture?

Yes
No

If yes, please specify: 


\section{Diversified Farming and Ranching on the Northern Great Plains}

26. Please specify whether you use the following kinds of fertilizers in your operation, and where you get them (e.g., "on-farm", "purchased from local dealer two miles away," etc.).

Manure

Compost

Green manures (N-fixing

cover crop)

Fish emulsion or other foliar

fertilizer

Other OMRI approved

commercial fertilizers

Mineral powders

Synthetic fertilizer

Other (please specify)

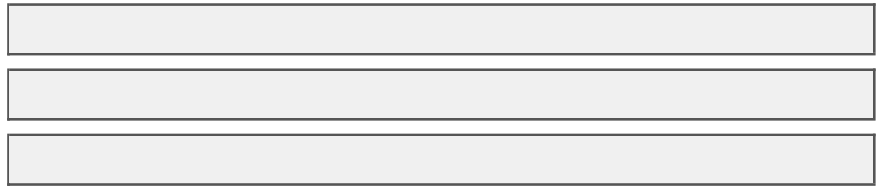

27. Please specify whether you use the following off-farm inputs to manage insect pests

Г OMRI approved insecticides

- Synthetic insecticides

O Oils

Г Sticky traps

- Pheromones

$\square$ Other (please specify):

Other:

28. Please specify whether you use the following off-farm inputs to manage plant pathogens

- OMRI approved fungicides/bactericides

Г Synthetic fungicides/bactericides

OMRI approved nematocides

Synthetic nematocides

○ Other (please specify)

Other: 


\section{Diversified Farming and Ranching on the Northern Great Plains}

29. Please specify whether you use the following off-farm inputs to manage weeds

— OMRI approved herbicides

Г Synthetic herbicides

$\Gamma$ Weed flamer

Weed roller

Diesel (through tillage, mowing, or swathing)

Other (please specify)

\section{Where does your irrigation water come from? (Please check all that apply.)}

— Groundwater

— Surface water from an irrigation district

— Surface water independent of an irrigation district

— Rainwater collection on your farm

\section{Do you use water conservation practices on your farm/ranch? (Please check all that} apply.)

- Limiting water use

- Plant crops with minimal water needs

$\square$ Monitoring water use of green manure crops for timely termination

$\Gamma$ Monitoring soil moisture

$\square$ Monitoring plant \& weather for precise estimate of water need

$\lceil$ Water conserving tillage

- Soil cover, mulches or residue to prevent surface evaporation

— Perennial windbreaks

Г Snow trapping

$\Gamma$ Rainwater collection

Use of recycled wastewater

C Conserving irrigation practices (such as low pressure drop nozzles, drip, irrigation water monitoring - PLEASE SPECIFY BELOW)

$\lceil$ Other (please specify)

Conserving irrigation practices or other practices not in the list 


\section{Diversified Farming and Ranching on the Northern Great Plains}

\section{Do you or any of your farm partners hold off-farm/off-ranch jobs}

O Yes

No

If yes, please specify the jobs held and whether they are part-time or full-time:

33. How many permanent employees do you have, not counting farm/ranch partners?

Permanent employees:

34. In terms of profitability of your operation in 2011, would you say it was:

Very profitable?

Profitable?

Break-even?

Operating at a loss?

Operating at a large loss?

35. What age are you and your farm/ranch partners?

You:

Partner 1

Partner 2

Partner 3

Partner 4

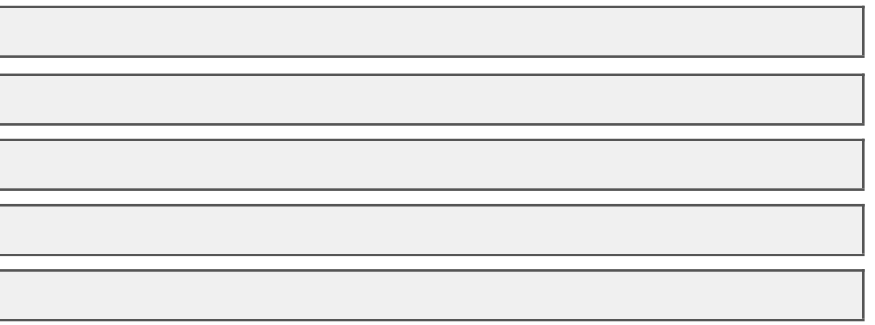

36. What is the highest level of education you and your farm/ranch partners have completed?

\begin{tabular}{|c|c|c|c|c|c|}
\hline & You & Partner 1 & Partner 2 & Partner 3 & Partner 4 \\
\hline Some high school & 0 & 0 & 0 & 0 & 0 \\
\hline High school/GED & 0 & 0 & 0 & 0 & 0 \\
\hline $\begin{array}{l}\text { Some college or vocational } \\
\text { training }\end{array}$ & 0 & 0 & O & O & O \\
\hline Two-year degree & 0 & O & 0 & 0 & 0 \\
\hline Four-year degree & 0 & 0 & 0 & 0 & 0 \\
\hline Master's degree & 0 & O & 0 & 0 & 0 \\
\hline Ph.D. degree & 0 & 0 & 0 & 0 & 0 \\
\hline Don't know & 0 & 0 & 0 & 0 & o \\
\hline
\end{tabular}




\section{Diversified Farming and Ranching on the Northern Great Plains}

37. If applicable, what was the educational field/discipline of the degree?

You

Partner 1

Partner 2

Partner 3

Partner 4

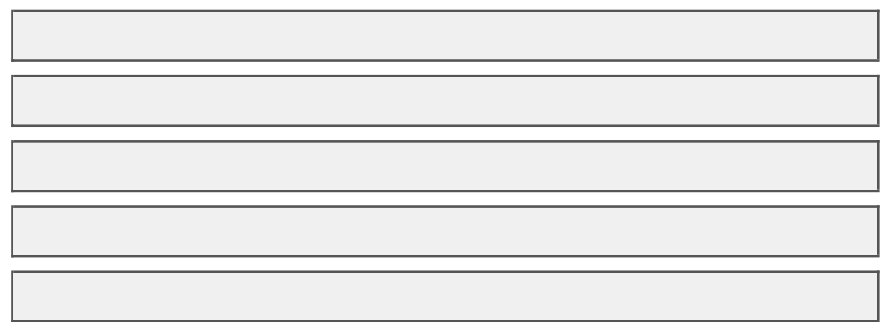

38. What ethnicity are you and your farm/ranch partners?

You

Partner 1

Partner 2

Partner 3

Partner 4

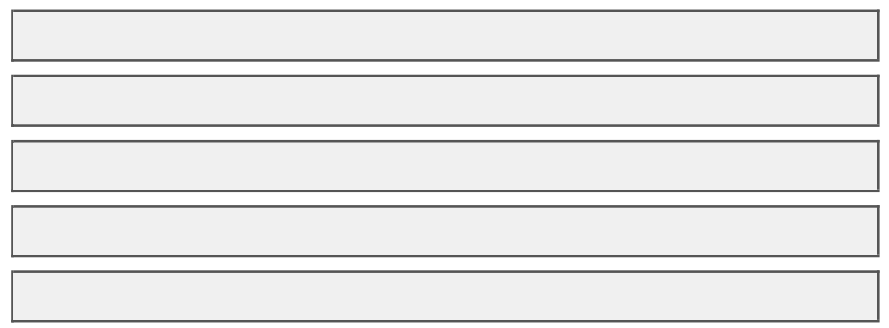

\section{What gender are you and your farm/ranch partners?}

You

Partner 1

Partner 2

Partner 3

Partner 4

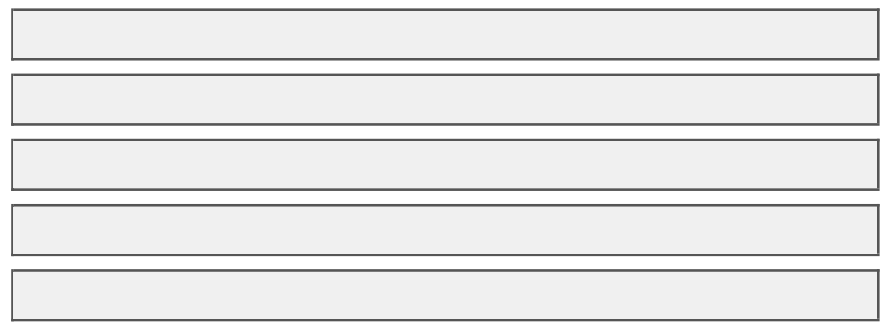

40. Is there anything else you would like to add?

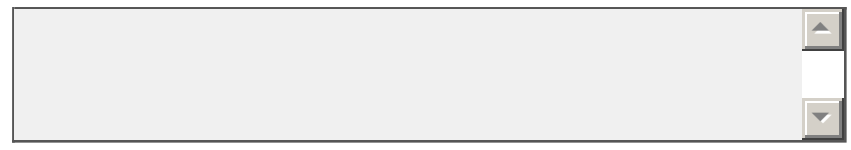

You are done! Thank you again for your participation. I look forward to speaking directly with you on your farm/ranch.

Please feel free to contact me with any questions or concerns at lizcarlisle@berkeley.edu

This project is generously supported by a National Science Foundation Graduate Research Fellowship. 


\section{Appendix 3: Descriptions of "Paradigm Shift" -- Interview Data}

"There's actually a shift in the thought process and I really believe it boils down to spirituality as much as anything else. It's almost like you have a WIIWQR RXUfaith and then you understand that the other way wasn't the right way to do it. That's not the way Mother Nature wants things to be done."

"This production system isn't just about taking everything for your own benefit ... it's a way of farming things but still leaving something."

Farmer: My intention has changed from making money to growing good quality healthy food ... and that makes a big difference.

LC When did that shift happen?

Farmer: About two years ago.

LC: The same time you said you started thinking about the soil as a living organism. Farmer: Absolutely.

LC: What precipitated it?

Farmer: I think it was just a natural progression. It's just an evolution almost. It's kind of like you were talking about, you focus on one thing, you don't see some of the other things .... I've learned a lot and things sink in now. It's like I understand the big picture more.

LC: What has been your most valuable lesson in trying to farm the way you farm? Farmer: That's a hard one. I guess, keep trying. If you try something and it fails, you just learn from it, but keep trying, and always consider soil health; don't concentrate on which crop is the most economically valuable. Do everything for soil health."

"It's really fun to work on the soil, to see how it invests in your future, after coming from the conventional mindset of an annual crop with annual payoff."

"We should be building stronger root systems, wider leaves, longer leaves, better nutrient cycles and water cycles over time. Leave things greener longer [using cover crops or perennial vegetation] and you're harvesting more sunlight and you're having more blossoms. The whole thing works on itself."

"I have a feeling that the more you take off the land, the more's not in the land. The land's got its limits on what it can make, so if I have a bad crop it doesn't really bother me."

"Most of the plants are multifunctional - how they feed microbes, put nitrogen in the ground, utilize phosphate. That's why rotations work, I think - each plant has a different function." 
"Take care of the earth and then the earth will take care of us."

"Everyone is not going to go out on the ledge all the way to organic, but getting them on the continuum of organic/sustainable/stewardship/conservation, then they would start to move down through all of those. Once they figured out, 'I'm not having as much evaporation of water in the summer, I can keep my soil covered with a nitrogen fixing crop, I have all this biomass' ...their brain couldn't quit after they had taken one step off the entrenched conventional wisdom. They began to have fun with farming again."

"In organic systems you have to be playing the long game. There are no short-term fixes, so you have to be patient. Like with the spurge, the easiest way to take care of it is with herbicide, you know, burn it down and be done with it. But that's not how it works in agriculture. You have to be patient, everything is not going to happen this year."

"Take care of the bird population and you're doing good things. That's a good measurement. When your bird population comes up, everything's working in harmony." 


\section{Appendix 4: Soil Water Conservation Strategies -- Survey and Interview Data}

Nine of fifteen interviewed producers farmed without any irrigation, while two had nonirrigated farms, but leased some irrigated land. All producers worked with at least some non-irrigated land, and all cited water as a critical limiting factor for their operations.

The most important water conservation strategy, mentioned by all but one interviewee, was maintaining soil cover throughout the year. Cover crops and mulches were used in cultivated areas, and producers with livestock often rotated these areas with perennial pasture. Two producers were permanently re-vegetating substantial cultivated areas with perennial forage.

By virtue of being part of the value chain, all respondents were planting at least one low water need crop, since that is what the value chain markets. Many had built on this foundation by using soil water conservation as their major variable for rotation planning, choosing low yield/high value crops, or reducing their seeding rates and plant populations to match soil moisture.

Twelve explicitly mentioned soil moisture monitoring as an important part of their water conservation strategy, and of the three that did not, two had a relatively small share of cultivated land, comparative to perennial forage.

Eleven practiced some form of water conserving tillage, but only one producer had fully eliminated tillage. The no-till farmer felt his categorical rejection of tillage was the cornerstone of environmentally responsible management on his farm; but another farm household referred to tillage as a key tool for organic management and quipped, "if you're not tilling, you're not farming." Most producers used some tillage, but tried to reduce its impact by leaving untilled borders, plowing less frequently and at a shallower depth, using lighter equipment, or seeding directly into stubble.

Six producers told me they were snow trapping to capture winter moisture. Perennial windbreaks were the most common strategy, but snow moisture could be retained using any form of soil cover. One producer had planted sunflowers for snow trapping purposes: he planned to leave the stalks in the field over the winter after selling cut flowers during the growing season.

Two producers were trialing dryland vegetables, one of whom was interested in saving seed to adapt varieties for non-irrigated conditions. Although most producers were working with such dryland conditions, three mentioned conservation irrigation practices as a key part of their water conservation strategy. 
Appendix 5: Enterprise Diversification - Additional Survey and Interview Data

Case study producers had substantially diversified their enterprises even within broad categories. Fifty-three percent sold grain for multiple end uses: food, feed, malting, biofuel, cooking oil, seed - one even sold his peas for wildlife food plots. Since farmers often didn't have to decide which of these markets to sell into before planting, this diversity of options provided a price floor for higher value markets and an alternative if their crop didn't meet quality requirements for a particular end user. Similarly, one couple maintained three distinct community supported agriculture operations (grain, livestock, vegetable).

In another form of enterprise diversification, one farm household described three different types of arrangements they have with buyers. They sell $40-50 \%$ of their crop by accepting prices offered by processors, $30 \%$ through contracts they negotiate, and $30 \%$ through loose arrangements to plant a particular number of acres, with final terms specified at harvest. This diversity of contract relationships provides a balance of stability and flexibility that helps buffer against the volatility of ecological and economic conditions to which these farmers are subject. 
Appendix 6: Formal Farmer Networks - Survey and Interview Data

Attempting to coordinate multi-farm cooperation and even out variability in producers' access to it, were a handful of formal farmer networks. In quantitative surveys, most respondents cited such networks, like the nonprofit Alternative Energy Resources Organization (AERO) or Montana Organic Association (MOA) as "moderate" sources of support and accountability, with remaining responses scattered across the spectrum from 1 to 5. While such networks were key for several producers, their importance for any given household depended on how long they had been farming, their level of access to like-minded people outside of such groups, and their ability to attend group meetings. Formal groups were most important for producers who were either early on in their transition, insufficiently connected to other members of their moral economy, or both. For these producers, formal groups provided a means of establishing a community - often to replace the one they had lost when abandoning conventional production.

AERO - a "citizen's renewable energy organization" founded in 1974 as a corollary to environmental activism against coal development - was the most frequently cited of these supportive groups. "AERO's been hugely important," said a young couple that had been farming for four years. "Just when we start to think that maybe what we're doing isn't really worth it, the sustainable ag community does something or says something. Like last year, we got that AERO award, which was just a huge boost to our resolve." AERO had served a similar support role for a previous generation, for whom it had also been a technical assistance provider and even business incubator. Beginning in the 1980s, AERO membership - many of them farmers - had begun to focus squarely on sustainable agriculture as a key vehicle for orienting the region's economy away from fossil fuels.

"AERO had that community of like-minded folks," a sixty-three year-old producer recalled. "There was kind of a handful, half a dozen to a dozen [agroecological] farmers in the early eighties .... We were all AERO members so that was our community and we started visiting with what we wanted to do and what we wanted to accomplish. I mean, all of the founders of [the VBSC at the center of this study], AERO's what brought us together. And then, at that time, AERO was the clearinghouse for sustainable agriculture information as well as the community and the philosophical side of it. AERO was the one who basically took up that challenge of transitioning agriculture to be a renewable resource."

The Montana Organic Association was also mentioned by several growers as a source of support, and one farmer/rancher had been deeply engaged with Holistic Management International.

These contemporary groups, however, were merely the latest in a long line of civil society organizations that had been key to supporting these farmers' success. Ten producers were current or former members of the Farmer's Union, an association 
founded in 1902 in response to increasing concentration in grain markets. Under the motto "cooperation, legislation, education," the Farmer's Union had successfully organized producer cooperatives all over the American West, utilizing a grassroots strategy that folded the union's social change agenda into the everyday fabric of rural life. VBSC farmers recalled going to Farmer's Union camps as children and attending meetings with their parents, which were "a real community thing." "I'm a Farmer's Union member," one recently retired VBSC producer told me. "I go to the county convention and participate in the policy work. My folks were Farmer's Union. I can remember when the Farmer's Union had really active locals. There was one at the rural school where I went to school. I remember getting together and we'd all get around the piano and sing camp songs." Other producers had joined their parents at National Farmer's Organizations marches in the mid-seventies, advocating for a price floor for agricultural commodities. "That's another nice thing about organic," one of these producers told me, showing me the protest signs he had saved in his garage from the NFO marches he had attended with his father. "You get a little more fairness."

Many VBSC producers narrated a similar generational trajectory: grandparents who had been part of early wheat pools and cooperatives, parents who had bolted from increasingly stodgy farm organizations mid-century to join the Farmer's Union and National Farmer's Organization, and friends in their own generation who had drifted from these groups to join the Alternative Energy Resources Organization and early certification efforts in the 1980s. Now, they noted, young farmers were starting new groups. Nearly everyone I spoke to felt that the core values animating such efforts had been successfully passed down, irrespective of the fate of specific organizations.

One older VBSC grower, for whom the Farmer's Union had been so foundational to his outlook that he "couldn't separate church and my parents and the Farmer's Union in my mind," commented that other groups had in many ways supplanted the function of his beloved organization, whose vest he still wore to nearly every function. "It seemed like AERO replaced the Farmer's Union to me, with the new idealistic people thinking and coming up with new ideas," he said. "The Farmer's Union had that when I was kid, at least I thought so .... Now they're in the middle." Rather than try to reform the Farmer's Union or apologize for its evolution, this producer had enthusiastically joined the board of AERO. He had recently been given a Lifetime of Service Award by the Montana Organic Association, which clearly recognized the man's participation in all three groups as part of a common community effort. 
Appendix 7: Perspectives on the Conservation Reserve Program (CRP) - Interview Data

"CRP broke the back of traditional farming. The first year was 1985, and the average lease was twenty years. That generation of kids, they didn't learn. The machines were in the shed and they didn't come out. It did a lot to stop the small farms."

"You shouldn't be eligible for payments unless you're a working farmer."

"You can't tell me that CRP that has almost no diversity in its grass mixture is really providing any more wildlife habitat or care than our farm. I mean, I don't know for certain, but I'd like to see some studies on that."

[A couple with three young children explained that they could not afford to take over the husband's family farm, because his relatives would expect financial returns equivalent to their existing CRP lease payment].

"As I'm trying to return to the farm I'm expected to compete with that lease payment," "We can't compete with the federal government. What - $\$ 30$ an acre? There's no way, we just can't do it."

"As a person who wants to get into farming, it's extremely frustrating to have people that have ground that is in CRP, because that's the ground that we would want to go get ..." "Because you could certify it [as organic] right off the bat [much of the land in CRP would immediately meet the requirement that land be free of chemicals disallowed by the National Organic Program for at least three years], but these people are getting fat checks from the government."

"We've never been in the CRP. We've never used that, we've never taken advantage of that. We believe we can raise our own crop and we don't have to worry about grazing, emergency grazing [a designation which allows producers to graze their enrolled conservation lands if the county exceeds legislated drought thresholds]. We raise our crops and sell our crops and over the years, we've probably forgone a lot of income, but that isn't right. CRP should be made for wildlife habitat, but you shouldn't break it out as a pasture insurance. Every year they want the CRP, 'well I want to graze that.' Excuse me, we're paying not to graze that, but these guys think they deserve it. So we don't have any set aside. We produce everything off of every acre and we get paid for doing the right thing [crop rotations focused on soil health]."

"It's not a sustainable practice for the farming industry."

"People here are really nice and we've had really good discussions [about trying to buy additional land] but trying to break free even another 320 acres is ... and it's all in CRP, so I think one of the other disincentives at least in the state of Montana is the CRP program." 


\section{Appendix 8: Off-Farm Income - Survey and Interview Data}

Nine of fifteen households who responded to questions about household financed reported that at least one farm partner had an off-farm job (five were full time). In three of these households, both farm partners had a job. Seven said the main reason for their off-farm job was health insurance coverage, although guaranteed year-round income was important too. Four explicitly stated that they wanted to reduce off-farm work to spend more time on their diversified farming systems, multi-farm collaborative efforts, and participation in organizations, but could not afford to. However, four reported that having an off-farm job was important to them as another form of diversification. Particularly for farm wives, off-farm work provided intellectual, social, and professional opportunities not available on the farm, and one farmer's off-farm job was a political position that allowed him to advocate for policies to support resilience at larger scales. Although these four households appreciated the benefits of their off-farm work, however, they would have preferred not to depend on it for health insurance - as this constraint forced longer commutes, prevented off-farm workers from taking breaks to help with labor-intensive tasks like harvest, and made the elected official even more nervous about losing his next race.

Of the six households that did not earn off-farm income, three received Social Security plus military retirement and/or Medicare, and two were largely self-sufficient homesteads with strong religious values and access to strong church-based networks. 